\title{
Las Quínoas oncoids: a new deposit of microbialites in the Salar de Antofalla (Catamarca, Argentina)
}

\author{
*Patricio Guillermo Villafañe ${ }^{1,3}$, Agustina Inés Lencina ${ }^{1,2}$, Mariana Soria ${ }^{1}$, Luis Alberto Saona ${ }^{1}$, \\ Fernando Javier Gómez ${ }^{4}$, Guido Ezequiel Alonso5, María Eugenia Farías ${ }^{1}$
}

\author{
Laboratorio de Investigaciones Microbiológicas en Lagunas Andinas (LIMLA), Planta Piloto de Procesos Industriales Microbiológicos \\ (PROIMI), CONICET, Av. Belgrano y Pasaje Caseros S/N, 4000 San Miguel de Tucumán, Tucumán, Argentina. \\ pgvillafan@gmail.com; agustinalencina@gmail.com; soria_mns@hotmail.com; saona.luis.a@gmail.com; mefarias2009@gmail.com \\ 2 Centro de Investigaciones y Transferencias Catamarca (CITCa), CONICET, Prado 366, 4700 San Fernando del Valle de Catamarca, \\ Catamarca, Argentina. \\ 3 Instituto Superior de Correlación Geológica (INSUGEO), CONICET-UNT, Av. Presidente Perón S/N, 4107 Yerba Buena, Tucumán, \\ Argentina. \\ ${ }^{4}$ Centro de Investigaciones en Ciencias de la Tierra (CICTERRA), CONICET-UNC (Universidad Nacional de Córdoba), Vélez Sarsfield \\ 1611, Piso 2, Of. 4, Ciudad Universitaria, Córdoba, Argentina. \\ fernandogomez411@gmail.com \\ 5 Cátedra de Química General, Facultad de Ciencias Naturales e IML, Universidad Nacional de Tucumán (UNT), Miguel Lillo 205, \\ 4000 San Miguel de Tucumán, Tucumán, Argentina. \\ guidoealonso@gmail.com \\ * Corresponding author: mefarias2009@gmail.com
}

\begin{abstract}
The Salar de Antofalla (salt flat) is located in the Puna region of Catamarca, in northern Argentina. In this paper we report and provide the first descriptive data of Las Quínoas, a modern system of oncoids located in the western margin of the salt flat. Oncoids were studied by insitu logging, polished and thin sections analysis. In addition, the 16s rRNA genes of microbial mats associated with these oncoids were amplified and sequenced to characterize the microbial biodiversity. Oncoids present discoidal to subrounded morphologies and sizes up to $15 \mathrm{~cm}$ in diameter. They are scattered along channels, which originate from the groundwater springs of a wetland and enter the salt flat. Its macrostructure is concentric and composed by three zones: 1 . A nucleus zone built by clastic material in a carbonate matrix. 2. A well-laminated zone around the nucleus that shows two types of mesostructures: concentrically stacked spheroids (SS-C) and randomly stacked hemispheroids (SS-R), both showing an alternation of dense and dark micritic laminae with light micritic to microsparitic laminae. 3. A poorly-laminated zone, in the outermost sector of oncoids, with two types of mesostructures too: a laminated mesostructure composed also of an alternation of dense and dark micritic laminae with light micritic to microsparitic laminae, and a non-laminated mesostructure composed of agglomerated and cemented clastic material within a calcareous matrix (wackestones-packstones). Regarding the microbial diversity, the analyzed oncoids in this work are mainly inhabited by Proteobacteria (ca. 37.5\%), Bacteroidetes (ca. 25.0\%), and in less proportion Planctomycetes, Actinobacteria and Cyanobacteria.
\end{abstract}

Keywords: Oncoid, Microbialite, Salt flat, Holocene, Catamarca.

RESUMEN. Los oncoides de Las Quínoas: un nuevo depósito de microbialitos en el salar de Antofalla (Catamarca, Argentina). El salar de Antofalla se encuentra en la región de la Puna de Catamarca, en el norte de Argentina. En este artículo informamos y proporcionamos los primeros datos descriptivos de Las Quínoas, un sistema moderno de oncoides ubicado en el margen occidental de este salar. Ellos se estudiaron mediante registro in situ, análisis de secciones pulidas y delgadas. Además, los genes de ARNr 16s de tapices microbianos asociados con estos oncoides se amplificaron y secuenciaron para caracterizar la biodiversidad microbiana. Los oncoides presentan morfologías discoidales a subredondeadas y tamaños de hasta $15 \mathrm{~cm}$ de diámetro. Se encuentran dispersos a lo largo de canales, que se originan de 
las surgentes de agua de una vega y entran al salar. Su macroestructura es concéntrica y está compuesta por tres zonas: 1. Una zona de núcleo construida por material clástico en una matriz de carbonato. 2. Una zona bien laminada alrededor del núcleo que muestra dos tipos de mesoestructuras: esferoides concéntricamente apilados (SS-C) y hemisferoides apilados aleatoriamente (SS-R), ambos con una alternancia de láminas micríticas densas y oscuras con micríticas claras a microesparíticas. 3. Una zona pobremente laminada, en el sector más externo de los oncoides, también con dos tipos de mesoestructuras: una mesoestructura laminada compuesta por la alternancia de láminas micríticas densas y oscuras con láminas micríticas claras a microesparíticas, y una mesoestructura no laminada compuesta de material clástico aglomerado y cementado dentro de una matriz calcárea (wackestones-packstones). En cuanto a la diversidad microbiana, los oncoides analizados en este trabajo están habitados principalmente por Proteobacterias (ca. 37,5\%), Bacteroidetes (ca. 25,0\%), y en menor proporción Planctomicetes, Actinobacterias y Cianobacterias.

Palabras clave: Oncoide, Microbialito, Salar, Holoceno, Catamarca.

\section{Introduction}

Microbialites have been defined as organosedimentary deposits formed by the interaction between benthic microbial communities and detrital and/or chemical sediments present in marine, coastal or lacustrine environments (Burne and Moore, 1987; Riding, 2008). The communities of microorganisms that have given rise to these deposits, not only were supposed to be the first life forms 3,600 million years ago, but they also have been dominant during eighty percent of the history of the Earth (Schopf, 1996).

The formation of microbialites is controlled by the interaction of physical, chemical and biological processes that take place in the same environment where they are found (Grotzinger and Knoll, 1999; Riding, 2008; Gómez et al., 2014). Different macro, meso and microstructures result of the interaction of microbial (intrinsic) and environmental (extrinsic) processes (Dupraz et al., 2011). Logan et al. (1964) emphasizes the importance of distinguishing between different types of microbialitic structures, since these respond to environmental factors and, therefore, are important for paleoenvironmental interpretation.

The organo-sedimentary structures that have laminated fabrics and grow adhered to the substrate are called "stromatolites", while the non-adherent bodies with concentric lamination are called "oncolites or oncoids" (Burne and Moore, 1987). The correct interpretation of these structures is potentially useful in the reconstruction of environmental events (Dupraz et al., 2006; Mercedes-Martín et al., 2014).

However, the distinction of primary biotic signatures in ancient geological deposits is generally hampered by taphonomic and geochemical changes that occurred during taphocenosis and post-depositional diagenesis. In the absence of direct biological evidence, the study of the microstructure can provide valuable information for the identification of microbial processes (Reid et al., 2000; Suárez-González et al., 2014). Additionally, the microstructure can be interpreted based on the study of modern analogues, where processes can be directly observed and secondary alteration is largely absent, facilitating the identification and differentiation of biological and abiotic controlled signatures.

Nowadays, modern analogs of microbialitic systems have been recognized in the Bolivia and Argentina Altiplano-Puna region and in the Atacama Desert in Chile: the stromatolites of Salar de Socompa and Laguna Negra (Argentina) (Farías et al., 2011; Gómez et al., 2014), microbialites from Laguna Tebenquiche and Laguna Brava (Chile) (Farías et al., 2014), or the microbialites described for the Holocene of the Altiplano-Puna in the region of Chile and Bolivia (Risacher and Eugster, 1979; Jones and Renault, 1994; Rouchy et al., 1996; Valero-Garcés et al., 2001). In the Puna region of Argentina, 22 microbial systems have been recognized to date. Of which, four have been surveyed in Salar de Antofalla, a salt flat in Catamarca province. One of them is registered in the sector known as Las Quínoas (Farías, 2017a).

In this work, we characterize and describe the area of deposit, external and internal morphologies and the main biological signatures of Las Quínoas oncoids. This study constitutes the first scientific report on these oncoids in the Salar de Antofalla, and along with other studies of modern oncoids from different parts of the world, such as those located in the Canary Islands (Spain) (McMaster and Conover, 1966), Florida and the Bahamas (United States) (Gebelein, 1976), Bermuda and Grand Cayman Island (United Kingdom) (Gebelein, 1976; 
Jones and Goodbody, 1985), Pastos Grandes (Bolivia) (Risacher and Eugster, 1979), Burgundy (France) (Verrecchia et al., 1997), Rios Mesquite (Mexico) (García-Pichel et al., 2004), Laguna Negra (Argentina) (Gómez et al., 2014), among others; it aims to provide information for the interpretation of ancient analogue ecosystems.

\section{Geographical location and geological context}

Las Quínoas oncoids deposit is located at 3,334 m a.s.1. $\left(25^{\circ} 52^{\prime} 9.33^{\prime \prime} \mathrm{S}, 67^{\circ} 54^{\prime} 24.68^{\prime \prime} \mathrm{W}\right)$, in the western margin of Salar de Antofalla salt flat (Catamarca), at $2 \mathrm{~km}$ to the southeast of the village with the same name (Farías, 2017b) (Fig. 1A and B). The Salar de Antofalla basin has an area of approximately $500 \mathrm{~km}^{2}$ (Fig. 1B) and was described for the first time by Alonso et al. (1984). It belongs to the geological province of Puna, which corresponds to the southern tip of the Altiplano Andino Central (Jordan and Mpodozis, 2006).

This region present an arid to semiarid climate, characterized by a solar irradiance at the salt flat with impinging UV-B flux reaching $10 \mathrm{~W} \mathrm{~m}^{-2}$
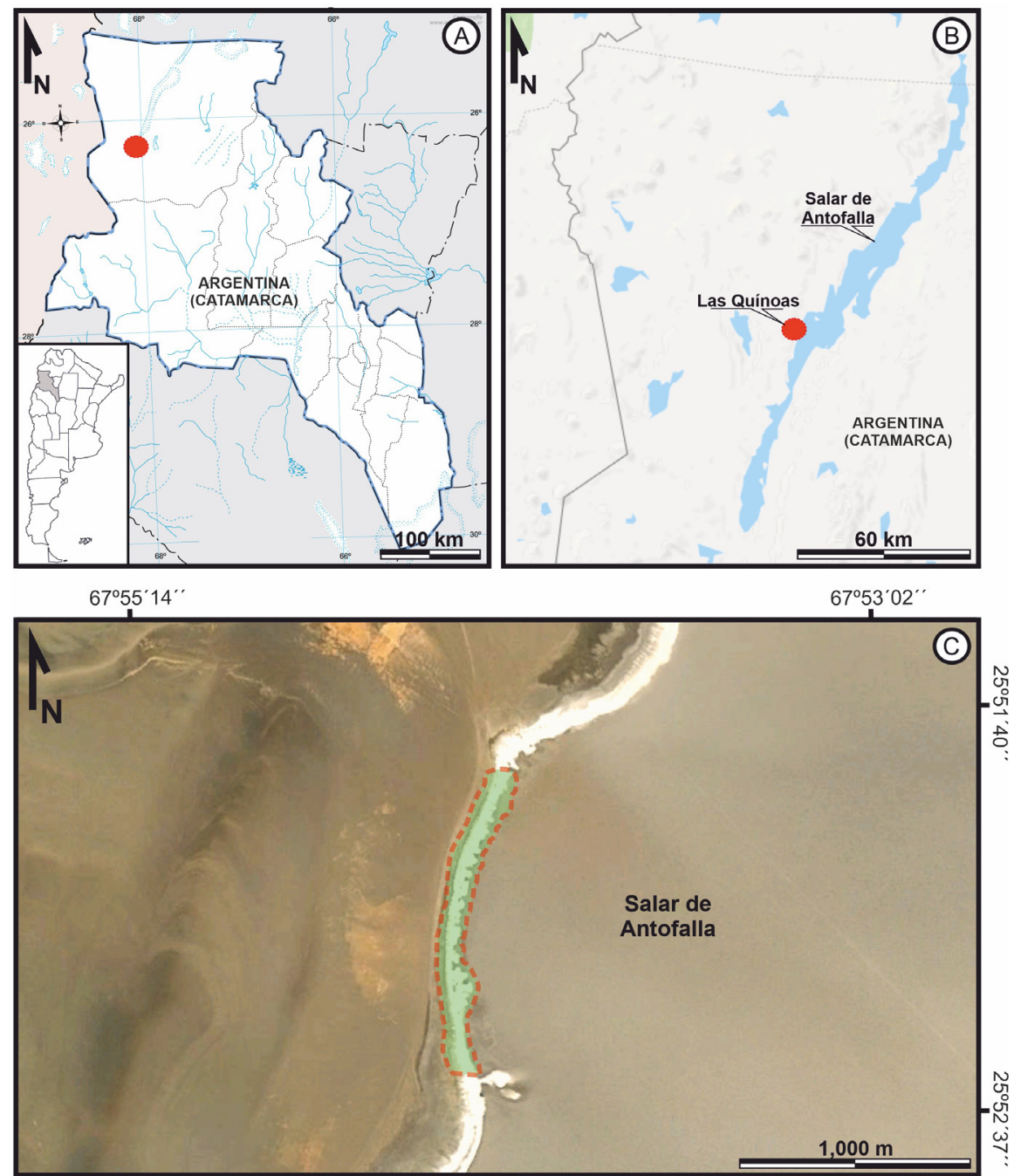

FIG. 1. Geographical location of the study area. A. Location of the study area (red circle) in the province of Catamarca, Argentina. B. Location of the study area (red circle) in the salt flat (Salar de Antofalla). C. Study area (dotted line) between the wetland to the west and the salt flat (Salar de Antofalla) to the east. Images created based on the Google Earth and Google Maps softwares. 
(Albarracín et al., 2016), average annual temperatures of $4.7^{\circ} \mathrm{C}-5.3{ }^{\circ} \mathrm{C}$ (Conhidro, 2016) and great daily and seasonally temperature ranges (more than $30^{\circ} \mathrm{C}$ ) producing daily water freezing and thawing. Annual rainfall reaches a total of $400-500 \mathrm{~mm} / \mathrm{year}$ in the west and 100-200 mm/year in the east (Cajal, 1998), associated with the southern transport of moisture to the East of the Andes (Alonso et al., 2006).

Seasonal changes can be abrupt. Although 80\% of rainfall occurs in summer (January-February), but on inter-annual time scales this can be affected by the El Niño Southern Oscillation (ENSO) phenomenon (Cajal, 1998).

A steep local relief caused by contractional tectonism, volcanic activity, and sluggish erosion due to an arid climate (Kraemer et al., 1999) characterized the Puna region. The Western Cordillera to the west and the Sierra de Calalaste to the east surround the Cenozoic endorheic salt flat basin. These ranges are mostly composed of deformed metamorphic rocks intruded by several generations of granitoids and aplites (Paleozoic). The crystalline basement is nonconformably overlain by unmetamorphosed siliciclastic sediments (Permian age) followed by a thick alternation of mudstones, sandstones and volcanic rocks, interbedded with coquina beds and oolithic limestones (Early Jurassic) (Alonso et al., 2006). From the Late Eocene to the Early Pliocene sedimentation was characterized by different succession of nonmarine clastic sediments intercalated with pyroclastic rocks and lavas.

The Salar de Antofalla basin is internally drained and contains thick sequences of Miocene to recent continental evaporites unconformably overlying Late Eocene to Miocene clastic deposits (Alonso et al., 2006; Kraemer et al., 1999). The evaporitic deposits that make up the salt flat consist essentially of chlorides and sulfates of sodium, calcium, potassium, magnesium and lithium. The brines contained in the salt flat are generally thought to result from thermal springs and the leaching of surrounding rocks by the infiltration and passage of meteoric water through them, leading to the formation of dilute inflow waters that subsequently concentrate by evaporation. The brines hosted in salt flat aquifers show a typical increase in concentration from their margins to the nucleus (Hongn and Seggiaro, 2001).

Around the margins of the salt flat, the drainage water is either close to the surface or in the form of open water lagoons (Houston et al., 2011). Fresh water inlets, from precipitation and/or melting ice, into the salt flat give rise to a complex mixed-fluid interaction area at the margins. Such is the case of Las Quínoas wetland, where groundwater discharges and forms channels which extend perpendicularly from the alluvial deposits into the salt flat. Oncoids are broadly distributed lengthwise the channels, although they are concentrated primarily at the end of the channels where the flows open up forming fan-shaped sand and salt deposits. Oncoids are subaerially exposed and are affected by seasonal wet-dry cycles and daily ice melting processes (Farías, 2017a, b).

In salt flat water bodies, carbonate precipitation and also dissolution, could be linked with the mixedfluid interactions between hypersaline waters and more dilute fresh waters inputs. Several researches suggest that environmental factors like groundwater seepage, mixed-fluid interaction, strong evaporation and $\mathrm{CO}_{2}$ degassing influenced the formation of microbialites (Gómez et al., 2014). Furthermore, it is also reported that, groundwater discharge supplies nutrients and dissolved ions as well as a lower salinity environment, which have an important effect on the living conditions of microorganisms (Moore, 1993; Houston et al., 2011; Gómez et al., 2014; Suosaari et al., 2016; Warden et al., 2019).

\section{Methodology}

During the year 2017, a seasonal survey of Las Quínoas oncoids was carried out. It initiated with the delimitation of the study area, through the analysis of satellite images with the free software Google Earth and digital images obtained with a drone.

An in situ mapping of Las Quínoas sedimentary and oncoids deposits was carried out, where the disposition, abundance and variations in the distribution of these deposits were determined. With the mapping, a systematic sampling of the oncoids was carried out.

In the channels where the oncoids are present, it was measured: air and water temperature, $\mathrm{pH}$, conductivity, water velocity and dissolved oxygen. Eighteen water samples were obtained along the channels, in distal (wetland), middle and proximal (fan/ discharge) location with respect the salt flat edge. Calcium, Magnesium, Chloride, Potassium and Sodium contents were determined by ion chromatography. For this, the methods SM 2340 B Ed. 22 (Total Hardness), SM 4110 B Ed. 22 (Chloride), and ISO 
14911: 1998 (Magnesium, Potassium, Sodium and Calcium) were followed. The chemical analyses were carried out by the company Grupo Induser SRL.

The oncoids samples collected were sent to the Centro de Investigaciones Geológicas de la Universidad de la Plata (CIG-UNLP-CONICET) for the preparation of thin and polished sections. The analysis of the biodiversity associated with oncoids, and the digital documentation of the hand samples and the polished sections, was carried out in the Laboratorio de Investigaciones Microbiológicas de Lagunas Andinas, which belongs to the Planta Piloto de Procesos Industriales Microbiológicos (LIMLA-PROIMI-CONICET). The thin sections were analyzed with a petrographic microscope at the Instituto Superior de Correlación Geológica (INSUGEO-UNT-CONICET), which has a built-in Leica DFC 420 camera for taking microphotographs.

The study of the oncoids was performed in three stages. In the first stage, spatial distribution and external morphology were analyzed based on field and laboratory data, including aspects such as distribution and area covered by the deposit, location and geomorphological relationships, general external appearance, color, contact types and diameters. The spatial distribution of the oncoids was delimited following the descriptive criteria proposed by McMaster and Conover (1966), Gebelein (1976) and Gómez et al. (2014).

For the characterization of the external morphology the classification proposed by Verrecchia et al. (1997) was used and complemented by concepts raised by Pettijohn et al. (1973), Jones and Goodbody (1985) and Tucker (2009). While the colors were described using the Munsell Soil Color Charts 2014 edition.

In a second stage, the internal morphology was studied in the laboratory following the traditional multiscale approach (e.g., Shapiro and Awramik, 2000; Vennin et al., 2015; Suárez-González et al., 2019), separately describing the macrostructure (i.e., outcrop), mesostructure (i.e., hand specimen) and microstructure (i.e., thin section) features.

For the description of macrostructure and mesostructure aspects such as types of lamination, textures, presence of clastic material, among others, were considered. This was done based on the classifications proposed by Logan et al. (1964), Aitken (1967), Riding (1977) and Mingxiang (2007); complemented by the works of McMaster and Conover (1966), Gebelein (1976), Cohen et al. (1997),
Dexit (1984), Dahanayake et al. (1985), Lanes and Palma (1998) and Zanin et al. (2001).

Microstructure was analyzed studying parameters like types of laminae, microtexture, stacking, lateral and vertical continuity of the lamination, presence of hiatuses, porosity, among others. Description of the laminae was mainly based on the proposals of Ziai (1982), complementing the information with the concepts proposed by Sarjeant (1975), Monty (1976), Scholle (1978), Reid et al. (2003), Gómez et al. (2014) and Suárez-González et al. (2014); in order to characterize the lamination and interpret processes such as precipitation and accretion of carbonates. The description of the carbonates was carried out using the Dunham (1962) classification. While the percentage of porosity was estimated by point counting and its analysis was based on the classification proposed by Choquette and Pray (1970), the descriptive concepts of Alonso et al. (1987) and the genetic classifications proposed by Ahr et al. (2005, 2011).

The third stage consisted in the study of the biodiversity present in the superficial layers of microbialites. This study was done in the three zones that can be differentiated based on the textural and lithological characteristics of the oncoids (nucleus zone, well-laminated zone and poorly-laminated zone) (see results section). Nevertheless, in the nucleus zone, no organic useful remains for biodiversity studies were found. So the study focused on the superficial layers of the well-laminated zone and poorly-laminated zone because they are biologically active. A total of four samples were analyzed for each zone.

For the DNA extraction, the oncoids were submerged in PBS Buffer pH 7.5 supplemented with $15 \% \mathrm{NaCl}$ and subsequently subjected to sonication through an ultrasonic bath for $30 \mathrm{~min}$ in the Ultrasonic Cleaner (testlab) equipment. This procedure was the most efficient to remove the cells from the surface of the oncoids. Then, the supernatant was collected and centrifuged for $10 \mathrm{~min}$ at 10,000 g. Finally, the sediment obtained was used as a starting sample for the DNA extraction.

Total genomic DNA was isolated from the samples using the FastDNA SPIN Kit for Soil ${ }^{\mathrm{TM}}$ (MP-Biomedicals) according to the protocol provided by the manufacturer. For the Preparation of DNA libraries, in the High-throughput DNA Sequencing, $2 \mu \mathrm{g}$ of purified DNA was used in $50 \mu \mathrm{l}$ of TE Buffer. The V3 and V4 hypervariable region of 
the 16S rDNA gene was amplified using primers suggested by Klindworth et al. (2013): Bakt-341F and Bakt-805R. These primers work for amplifying both Bacteria and Archaea. The amplicons originated were sequenced on an Illumina MiSeq instrument using a MiSeq reagent kit v2 (500 cycles).

Sequencing data were analyzed through QIIME 2 software (2018-2), following the tutorials provided by the QIIME developers (Caporaso et al., 2010). QIIME 2 use the DADA2 algorithm and generate a procedure with higher resolution in comparison to methodologies grouping steps to generate OTUs by similarity. The taxonomic analysis was performed with a customized classifier using the Silva database (No. 132, April 2018) trained with 16S rRNA genes grouped in OTUs with $97 \%$ similarity.

\section{Results}

\subsection{Distribution of oncoids and external morphology}

The oncoids of Las Quínoas are distributed in approximately 18 channels, which include a narrow belt that extends about $1,200 \mathrm{~m}$ in a northsouth direction, in the transition area between a groundwater-fed wetland to the west and the salt flat (Salar de Antofalla) to the east (Figs. 1C, 2A and B). The wetland provides water flow into the salt flat and forms the channels (each of which are between 0.5 and $1.5 \mathrm{~m}$ wide) that extend perpendicularly an average distance of $10 \mathrm{~m}$ to $20 \mathrm{~m}$ (Fig. 2B and C).

Las Quínoas present important daily thermal amplitude, which can reach $20^{\circ} \mathrm{C}$ in winter and $27^{\circ} \mathrm{C}$ in summer. Our measurements indicate that water in the channels can reach a maximum temperature of $18^{\circ} \mathrm{C}$ degrees and a minimum of $-8^{\circ} \mathrm{C}$ (Table 1 ), generating daily freezing-thawing processes (Fig. 2D). The channels show a water average speed of $0.55 \mathrm{~m} / \mathrm{s}$, with a dissolved oxygen value of $9.79 \mathrm{mg} / \mathrm{l}$.

When the wetland water enters to the salt flat, a water mixing area is produced along the channels where the oncoids are found. In direction to the salt flat, water present chemical variations represented by significant increases in Calcium, Magnesium, Chloride, Potassium and Sodium (Table 1). A variation in the $\mathrm{pH}$ is also observed, which increases from 7.01 (distal) to 7.99 (proximal) (Table 1).

The oncoids are distributed along the channels, a greater concentration was observed towards the interior of the salt flat, where the flows open up forming fan-shaped sand and salt deposits. In relation to the position of the oncoids in the channels, a gradation was recognized regarding their sizes and shapes.

Based on their sizes and morphologies, two groups can be distinguished taking the descriptive criteria of Verrecchia et al. (1997) and Tucker (2009): One group represented by small sizes (diameters between $1 \mathrm{~cm}$ and $7 \mathrm{~cm}$ ) with sub-rounded to rounded morphologies, and another group represented by larger oncoids (diameters of between 10 and $18 \mathrm{~cm}$ ) with discoidal morphologies. The gradation regarding the size and shape of the oncoids was controlled by their position in the channels. Upstream and in the middle parts of the channels, sub-rounded oncoids of sizes smaller than $8 \mathrm{~cm}$ predominate (Fig. 2E). In these areas of the channels, water depth is approximately $15 \mathrm{~cm}$.

Near the discharge area of the channels, in the salt flat -where the channels open in the form of fans- the size of the oncoids increases (they exceed $10 \mathrm{~cm}$ ), as well as the presence of the discoidal shapes (Fig. 2F). In these areas the water depth is reduced to approximately $7 \mathrm{~cm}$.

On the other hand, distinctive features of its external surface were observed (Fig. 3A), such as surfaces with a clastic texture given by the agglomeration of particles up to $0.2 \mathrm{~cm}$ in diameter (Fig. 3B) that are characterized by their high sphericity and by angular to subangular roundnesses (Pettijohn et al., 1973), with contacts of the tangent to full type (sensu Tucker, 2009). While other oncoids present sectors with relatively smooth or botroidal external surfaces (Fig. 3C). In general, the oncoids are hardly internally cemented, with an average density of $2.364 \mathrm{~g} / \mathrm{cm}^{3}$ and an external yellowish coloration (5 Y 7/6, Munsell Color System).

\subsection{Internal morphology}

\subsubsection{Macrostructure}

Las Quínoas oncoids have an internal concentric macrostructure, with lamination around a nucleus. This macrostructure is not homogeneous, because presents textural and lithological variations. Within the oncoids three zones can be differentiated based on their textural and lithological characteristics. A nucleus zone made up of various lithologies in the central part of the sample, a well-laminated zone where the lamination is continuous around the nucleus, and a poorly-laminated zone in the external part of the sample where the lamination 

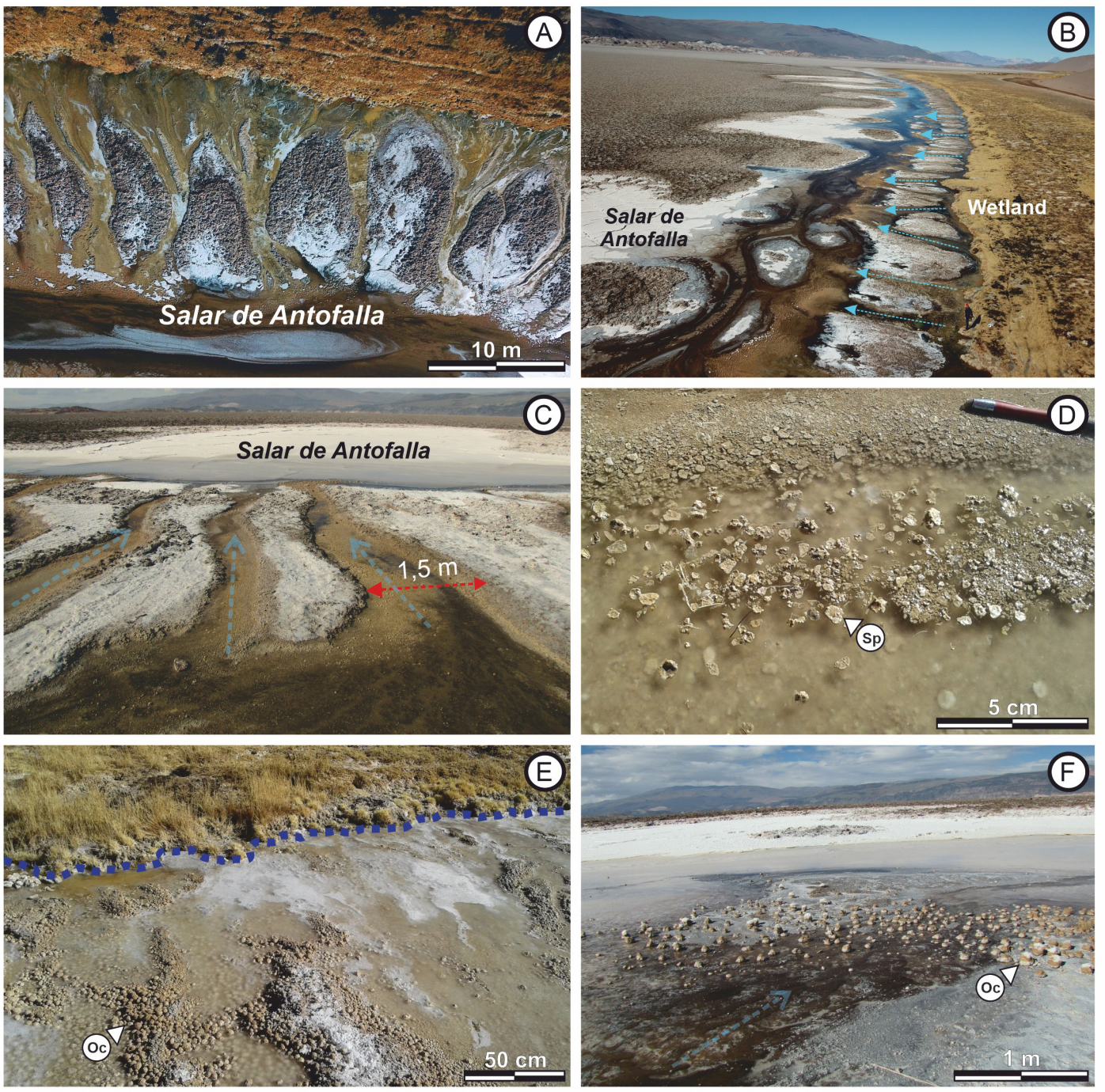

FIG. 2. Study area and spatial distribution of Las Quínoas oncoids. A-B. Narrow transition area developed between the salt flat and the wetland, in which channels flow into the salt flat and where the oncoids are deposited. Sky-blue arrows indicate the direction of water flow. C. Channels of up to $1.5 \mathrm{~m}$ width, which flow into the salt flat. Sky-blue arrows indicate the water flow direction. D. Freezing process of channels water with sediments ( $\mathrm{Sp}$ ) trapped in the ice. E. Channel distal area with rounded oncoids (Oc) of small diameters (less than $7 \mathrm{~cm}$ ), close to the wetland (dotted blue line). F. Channel discharge area in the salt flat (proximal area), where the channels open in the form of fans. In this area the size of the oncoids (Oc) increases ( $>10 \mathrm{~cm}$ in diameter) and they have discoidal morphologies. Sky-blue arrow indicates the direction of water flow.

is interrupted by the presence of clastic material (Fig. 4A).

\subsubsection{Mesostructure}

The Nucleus zone of the oncoids is well defined and has irregular morphologies, with diameters not exceeding $8 \mathrm{~cm}$ (Fig. 4B). Two types of nuclei are distinguished:
Type 1 nuclei: They have diameters between $0.5 \mathrm{~cm}$ and $3 \mathrm{~cm}$. They are composed of sub-rounded, less than $0.1 \mathrm{~mm}$-sized, clastic particles (including rock fragments, carbonate crusts and micritic intraclasts), immersed in a homogeneous micritic matrix (Fig. 4C).

Type 2 nuclei: They have diameters between $3 \mathrm{~cm}$ and $8 \mathrm{~cm}$, and are composed by rounded to 
TABLE 1. WATER CHEMICAL COMPOSITION ALONG THE CHANNELS.

\begin{tabular}{cccc}
\hline Parameter & Distal & Center & Proximal \\
\hline $\mathrm{pH}$ & 7.01 & 7.56 & 7.99 \\
Temperature & $-8{ }^{\circ} \mathrm{C}$ to $18{ }^{\circ} \mathrm{C}$ & $-8{ }^{\circ} \mathrm{C}$ to $18{ }^{\circ} \mathrm{C}$ & $-8{ }^{\circ} \mathrm{C}$ to $18{ }^{\circ} \mathrm{C}$ \\
Calcium & $7.9 \mathrm{mg} / 1$ & $493 \mathrm{mg} / 1$ & $32,100 \mathrm{mg} / 1$ \\
Magnesium & $<0.3 \mathrm{mg} / 1$ & $62.3 \mathrm{mg} / 1$ & $6,790 \mathrm{mg} / 1$ \\
Total Hardness & $20.7 \mathrm{mg} / 1$ & $1,490 \mathrm{mg} / 1$ & $108,000 \mathrm{mg} / 1$ \\
Chloride & $12.9 \mathrm{mg} / 1$ & $2,800 \mathrm{mg} / 1$ & $219,000 \mathrm{mg} / 1$ \\
Potassium & $1.1 \mathrm{mg} / 1$ & $35 \mathrm{mg} / 1$ & $5,130 \mathrm{mg} / 1$ \\
Sodium & $45.9 \mathrm{mg} / 1$ & $1,190 \mathrm{mg} / 1$ & $83,600 \mathrm{mg} / 1$ \\
\hline
\end{tabular}

Chemical composition, $\mathrm{pH}$ and temperature of water in the distal (wetland), middle and proximal (fan/discharge area) areas of the channels. The calcium, magnesium, chloride, potassium and sodium concentration and total hardness of the water are show in the different segments of the channels. From the wetlands area to the channels fan, a significant increase in the content of the elements is observed.
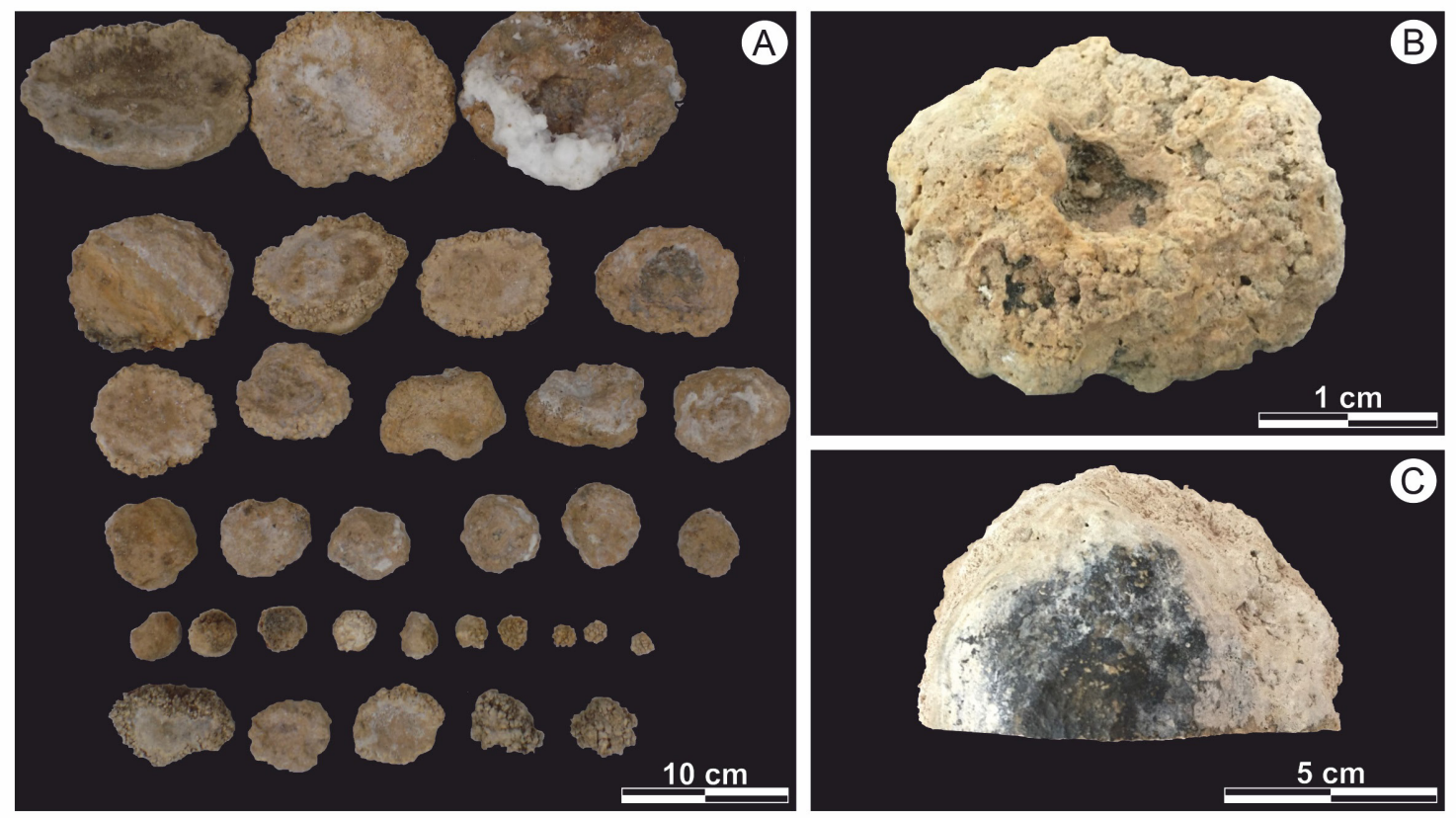

FIG. 3. External morphologies and sizes. A. Collected oncoids with different sizes and morphologies. B. Oncoid with subrounded to discoidal morphology. External surface with clastic texture formed by the agglomeration of particles up to $0.2 \mathrm{~mm}$ in diameter. C. Oncoid with discoidal morphology. External surface shows smooth texture.

sub-rounded mini-oncoids (named for their millimeterscale size), immersed in a calcareous matrix, and accompanied by rock fragments, carbonate crusts and even reworked micritic intraclasts like nuclei type 1 (Fig. 4D).

The well-laminated zone can reach a thickness of up to $5 \mathrm{~cm}$ and is characterized by an alternation of calcareous laminae (Fig. 5A). The lamination is laterally continuous and is densely packed (Fig. 5B) with occasional presence of clastic material (Fig. 5C). This zone shows two types of mesostructures: Lamination is continuous around the nucleus and represented by stacked concentric laminae that gives rise to what Logan et al. (1964) define as concentrically stacked spheroids (SS-C) (Fig. 5D). Outwards, lamination show different orientation, 

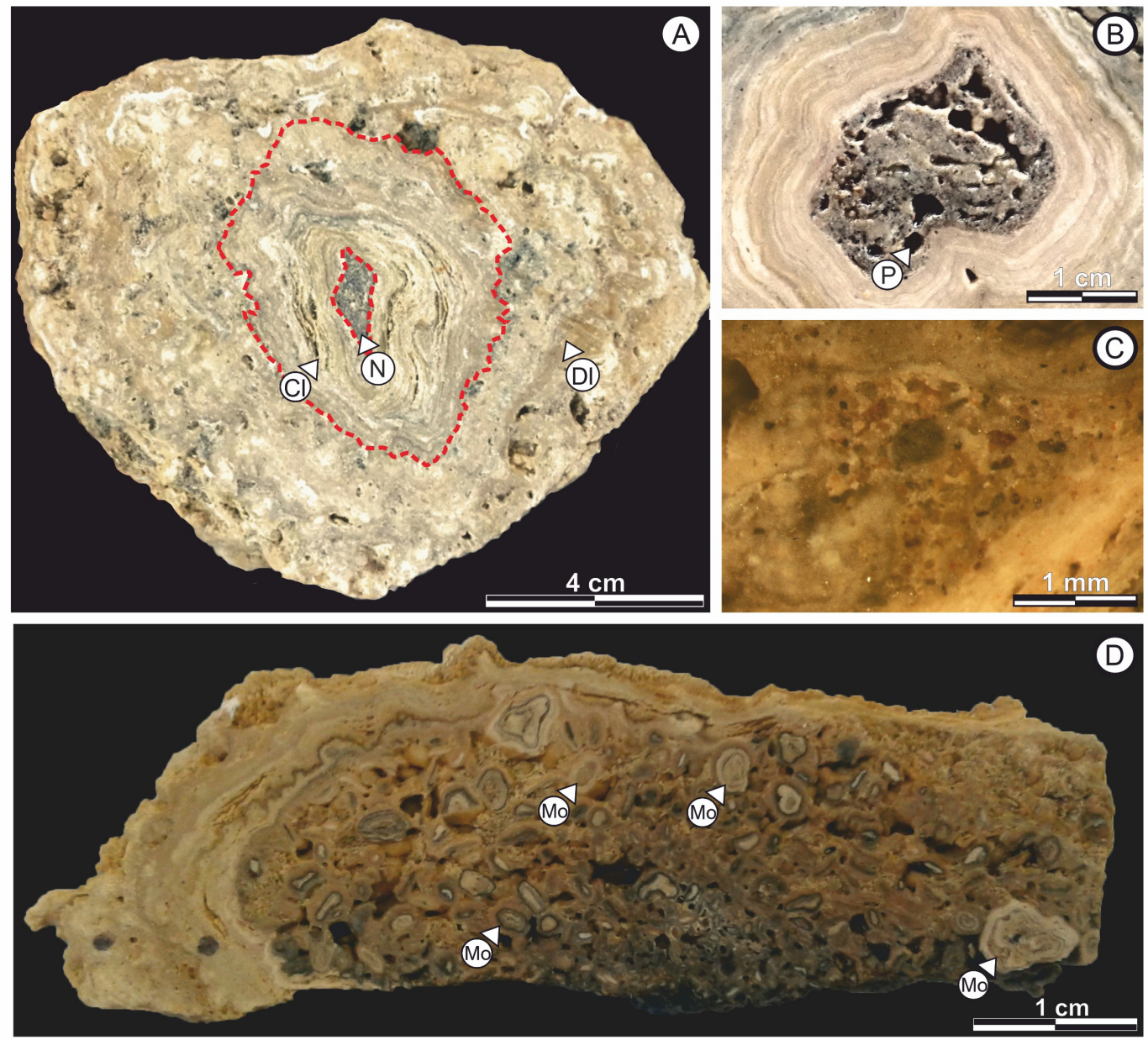

FIG. 4. A. Concentric macrostructure with different types of zones: nucleus zone $(\mathbf{N})$, well-laminated zone $(\mathbf{C l})$ and poorly-laminated zone (DI). Mesostructure of nucleus zone. B. Smalls and well defined nuclei (diameters from $0.5 \mathrm{~cm}$ to $2 \mathrm{~cm}$ ) with irregular morphology and high porosity (P). C. Type 1 nuclei: presence of clastic material of different lithologies, submerged in a calcareous matrix. D. Type 2 nuclei: large nuclei (diameters from $2 \mathrm{~cm}$ to $5 \mathrm{~cm}$ ) with mini-oncoids (Mo) (rounded to subrounded and with concentric internal structure) submerged in a calcareous matrix.

partially overlapping previous laminae (Fig. 5E), which gives rise to what Logan et al. (1964) denominated randomly stacked hemispheroids (SS-R).

The lamination can be exposed and truncated on the surface of the oncoid, due to effects of erosion or lack of sedimentary accretion. In these cases, the oncoid acquire an almost smooth external morphology (Fig. 5F). Well-laminated zone can be recognized in all the oncoids of this deposit, with more or less development, regardless of its position in the channel (Fig. 6).

The poorly-laminated zone, developed in the external sectors of the largest oncoids, can reach a thickness of up to $9 \mathrm{~cm}$. This zone shows two types of mesostructures, which alternate with each other: On the one hand, a mesostructure composed of poorly-developed irregular laminae, describing concave and convex structures, often interrupted laterally by the presence of clastic material (Fig. 7A). When these sectors of discontinuous lamination are superficially exposed, the oncoids acquire external botroidal morphology (Fig. 7B). On the other hand a non-laminated mesostructure composed by the agglomeration and cementation of clastic material together with mini-oncoids immersed in a calcareous matrix that could be classified as wackestones-packstones (Dunham, 1962) (Fig. 7C). 

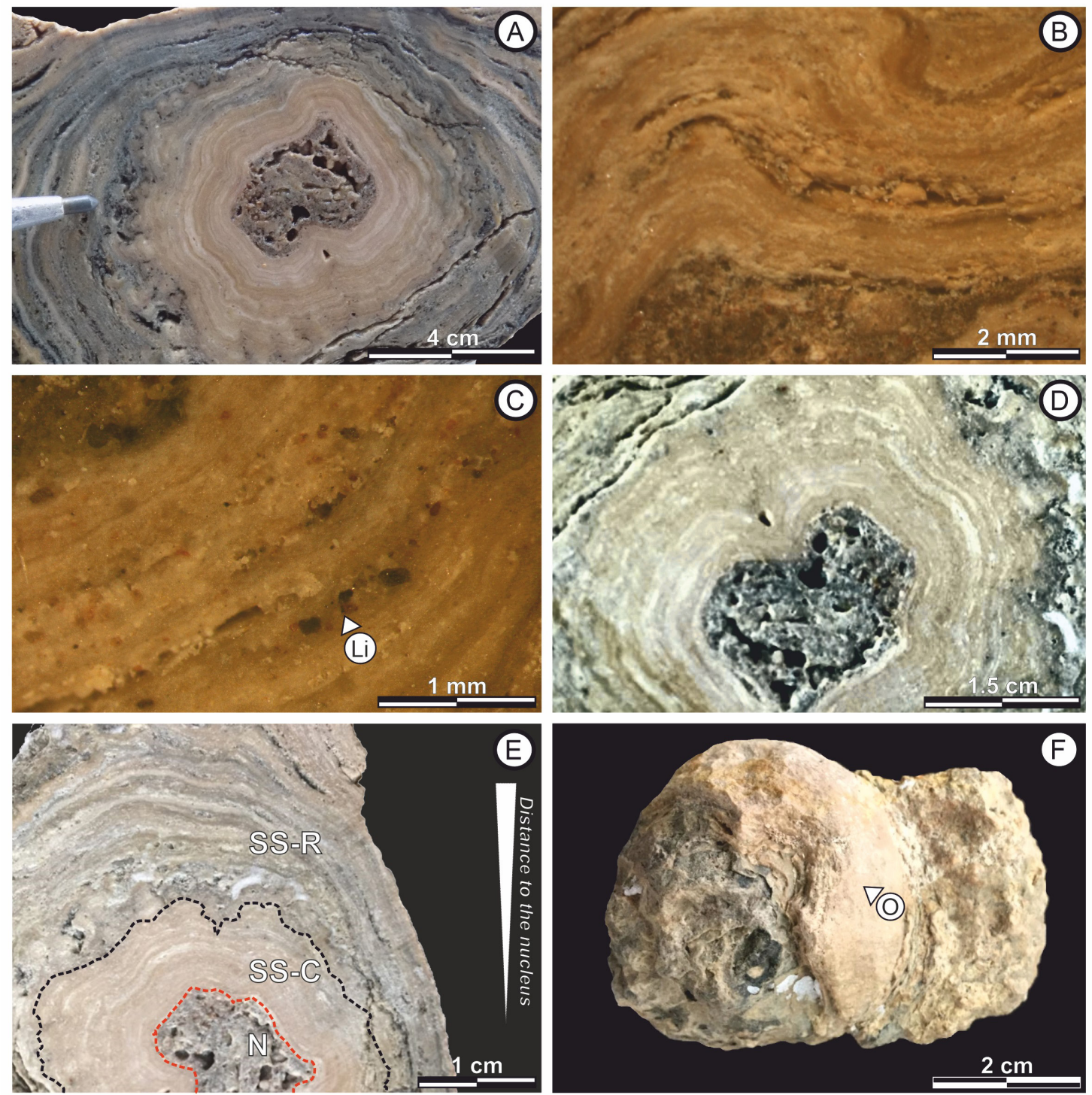

FIG. 5. Mesostructure of well-laminated zone. A. Area with continuous lamination developed around the nuclei. B. Superposition of laminae with continuous development and dense packing. C. Sporadic intercalation of lamina with a higher content of granular material (Li). D. Internal structure of the type concentrically stacked spheroids (SS-C) observed in the area closest to the nucleus. E. Internal structure of the type randomly stacked hemispheroids (SS-R). The black dotted line marks the limit with the SS-C type area, while the red dotted line indicates the limit among the SS-C area and the nucleus. F. Oncoid with smooth external morphology $(\mathbf{O})$ product of the surface exposure of this area.

The clasts vary in their composition (volcanic rock fragments, carbonate crusts and micritic intraclasts) and do not exceed one millimeter in diameter, while the mini-oncoids reach diameters greater than $1.25 \mathrm{~mm}$ and have rounded to sub-rounded morphologies. When this mesostructure is exposed superficially, the oncoid displays an irregular external morphology
(Fig. 7D). Poorly-laminated zone can be recognized only in the oncoids of the channels proximal (fan/ discharge) area (Fig. 6).

\subsubsection{Microstructure}

Nuclei of type 1 and type 2 are of sedimentary origin, composed of poorly selected clastic material 


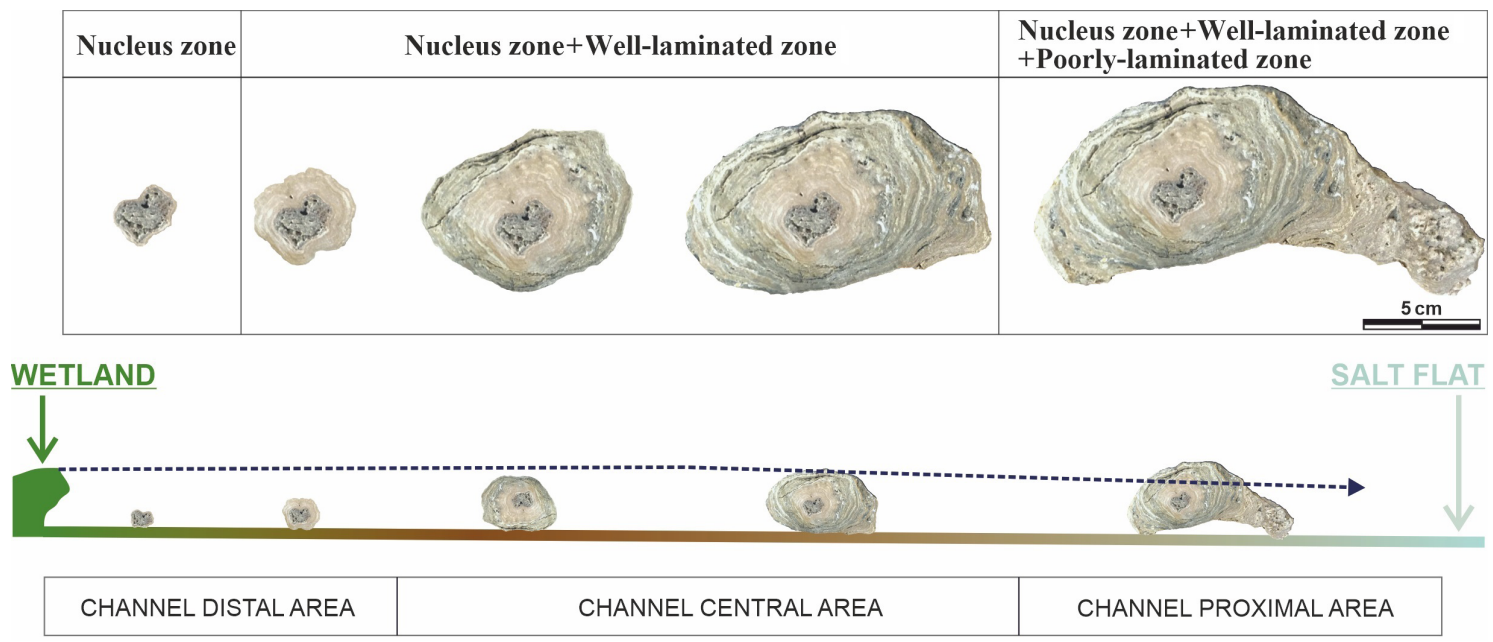

FIG. 6. Graph showing the relationship between the growth of oncoids, the position along the channels and the relative water depth (blue dotted line). In the channels distal area, only a small growth of the well-laminated zone around the nucleus zone is observed. As the oncoids are transported along the channels in direction to the salt flat, and remain below the water/air interface, their size increases as a result of the mineral precipitation and/or trapping and binding. This transport is episode due to seasonal changes in water streams and processes like daily water freezing and thawing. The channels central area shows a concentric growth of the well-laminated zone. However, when the size of the oncoid reaches the water-air interface, a tendency to preferential lateral growth is observed. Moving to the channels proximal area (fan/discharge area), the hydrodynamic energy is insufficient to continue with the oncoids transport, and the water level limits the vertical growth. In this area, favored by the sedimentary contribution, the poorly-laminated zone of the oncoids grow laterally suffering asymmetric thickening product of contributions and/or preferential precipitation. The distance between the wetland and salt flat is about $10 \mathrm{~m}$ to $20 \mathrm{~m}$.

and mini-oncoids immersed in a micritic matrix (Fig. 8A). In type 1 the clasts are smaller than $0.1 \mathrm{~mm}$ and can be composed of rock fragments, carbonate crusts and even reworked micritic intraclasts (Fig. 8B).

In the type 2 nuclei, in addition to clastic material, mini-oncoids are also present (Fig. 8A and C). These mini-oncoids present sizes up to $0.25 \mathrm{~mm}$ and spherical to discoidal morphologies. Its internal structure is concentric, characterized by the alternation of dark micritic laminae with clear microsparitic laminae around a detrital nucleus (Fig. 8C). Some mini-oncoids only present micritic lamination (Fig. 8C).

The porosity observed in the nucleus zone is mainly non-selective, mostly of the intragranular and intraclastic type, and to a lesser extent moldic type. It is also observed to a lesser extent by selective fabric porosity of the intergranular type (Choquette and Pray, 1970) (Fig. 8D). In type 1 nuclei porosity is approximately $10 \%$ to $15 \%$, while in type 2 nuclei increases to about $25 \%$ to $35 \%$.

The edges of the nucleus zone show evidence of transport and erosion, since the structures that make up the nucleus (e.g., mini-oncoids) are cut and the lamination of the well-laminated zone grows over a previously eroded and transported surface (Fig. 8D).

In the well-laminated zone, both the SS-C and the SS-R mesostructure have an "alternating lamination" microstructure (sensu Monty, 1976) characterized by the interbedding of dense and dark micritic laminae with light micritic to microsparitic laminae (Fig. 9A). However, in some sectors, isolated clotted-micritic or sparitic laminae are observed (Fig. 9B). The laminae are continuous and wavy, and their thicknesses are less than one millimeter. Laminae boundaries are sharp, and conform what is described as a tight texture (sensu Sarjeant, 1975) (Fig. 9A and B).

In the SS-R mesostructure, the laminae can be grouped in packages of different orientation separated by discontinuities. In several cases it is observed how the packages are interrupted, and a new lamination package grow overlapping with a new direction (Fig. 9C).

The porosity in the well-laminated zone does not exceed $10 \%$. It is represented mainly by fenestral 

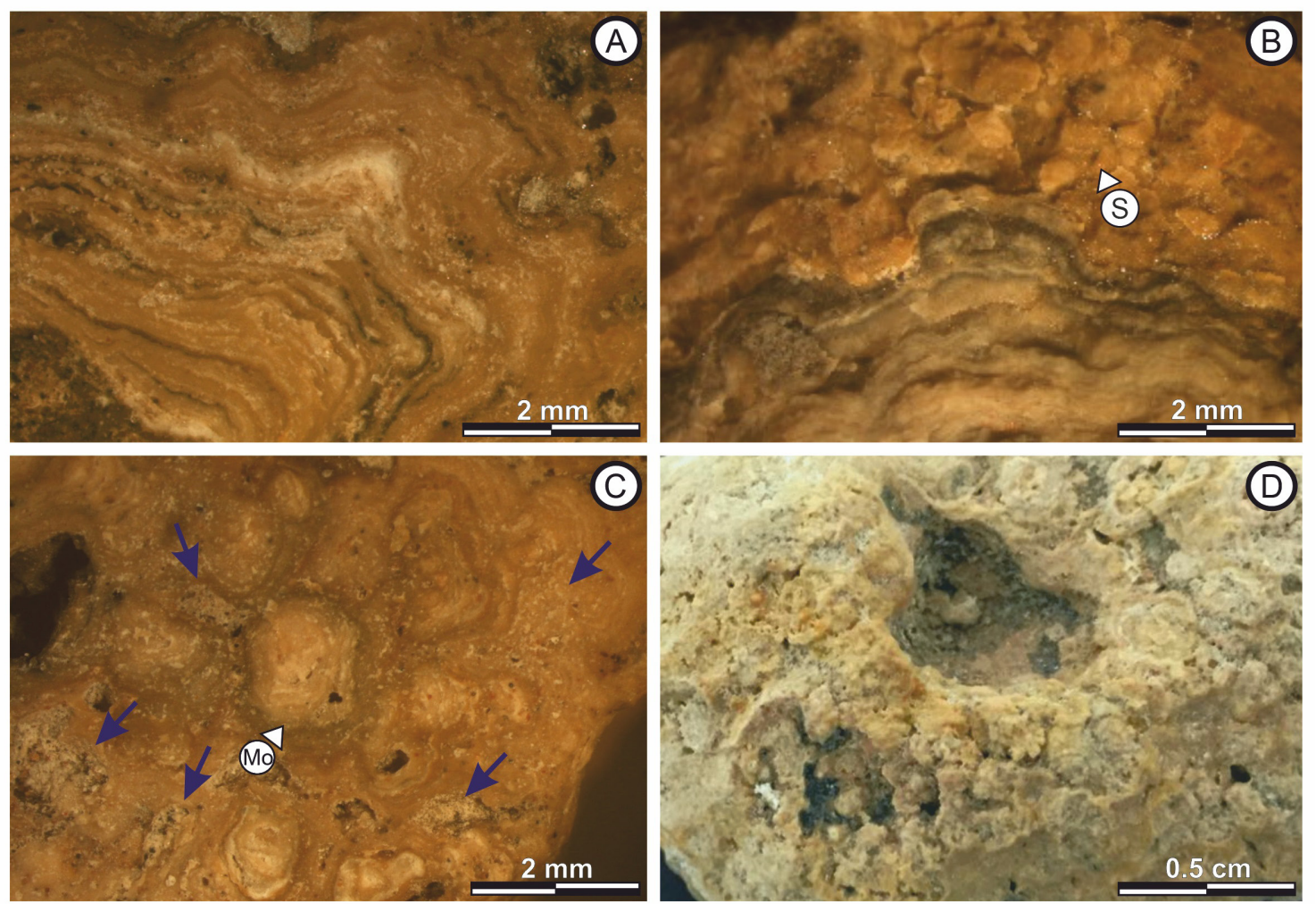

FIG. 7. Mesostructure of poorly-laminated zone. A. Area with sinuous lamination, describing concave and convex structures. The lamination present lateral interruptions. B. External morphology of botroidal type (S) product of the surface exposure of the sinuous lamination. C. Sectors without lamination (wackestones-packstones), conformed by detrital material (pointed by blue arrows), and mini-oncoids (Mo) with concentric internal lamination, immersed in a calcareous matrix. D. External morphology with clastic texture product of the surface exposure of this area.

pores type with irregular and elongated morphology (Choquette and Pray, 1970) (Fig. 9D). In addition, non-selective vug and moldic porosity (Choquette and Pray, 1970) are observed.

The microstructure of the poorly-laminated zone is composed by the alternation of dense and dark micritic laminae, with lighter micritic to microsparitic laminae, similar to the well laminated zone. The laminae have high sinuosity and are interrupted laterally (Fig. 10A and B). As we move away from the nucleus of the oncoids, the lamination becomes more irregular and discontinuous.

Non-laminated areas are composed of poorly sorted clastic material, immersed in a micritic matrix. They can be considered as wackestonespackstones based on Dunham's classification (1962). The clasts size is smaller than $0.1 \mathrm{~mm}$ and may be composed of mono-mineral particles, rock fragments, reworked micritic intraclasts and mini-oncoids (Fig. 10C).

The mini-oncoids are up to $0.25 \mathrm{~mm}$ in diameter, and show subspherical to discoidal morphologies. In the case of mini-oncoids, their internal structure is concentric, characterized by the alternation of dark dense micritic laminae with translucent micritic to microsparitic laminae around a detrital nucleus (Fig. 10D). Porosity in the poorly-laminated zone not exceeds $20 \%$ of the surface of the thin section. Non-selective fabric porosity of vug and moldic type, and selective fabric of intergranular type are observed (Choquette and Pray, 1970) (Fig. 10D).

\subsection{Biodiversity studies}

The results presented below correspond to the superficial laminae of the well-laminated zone and 

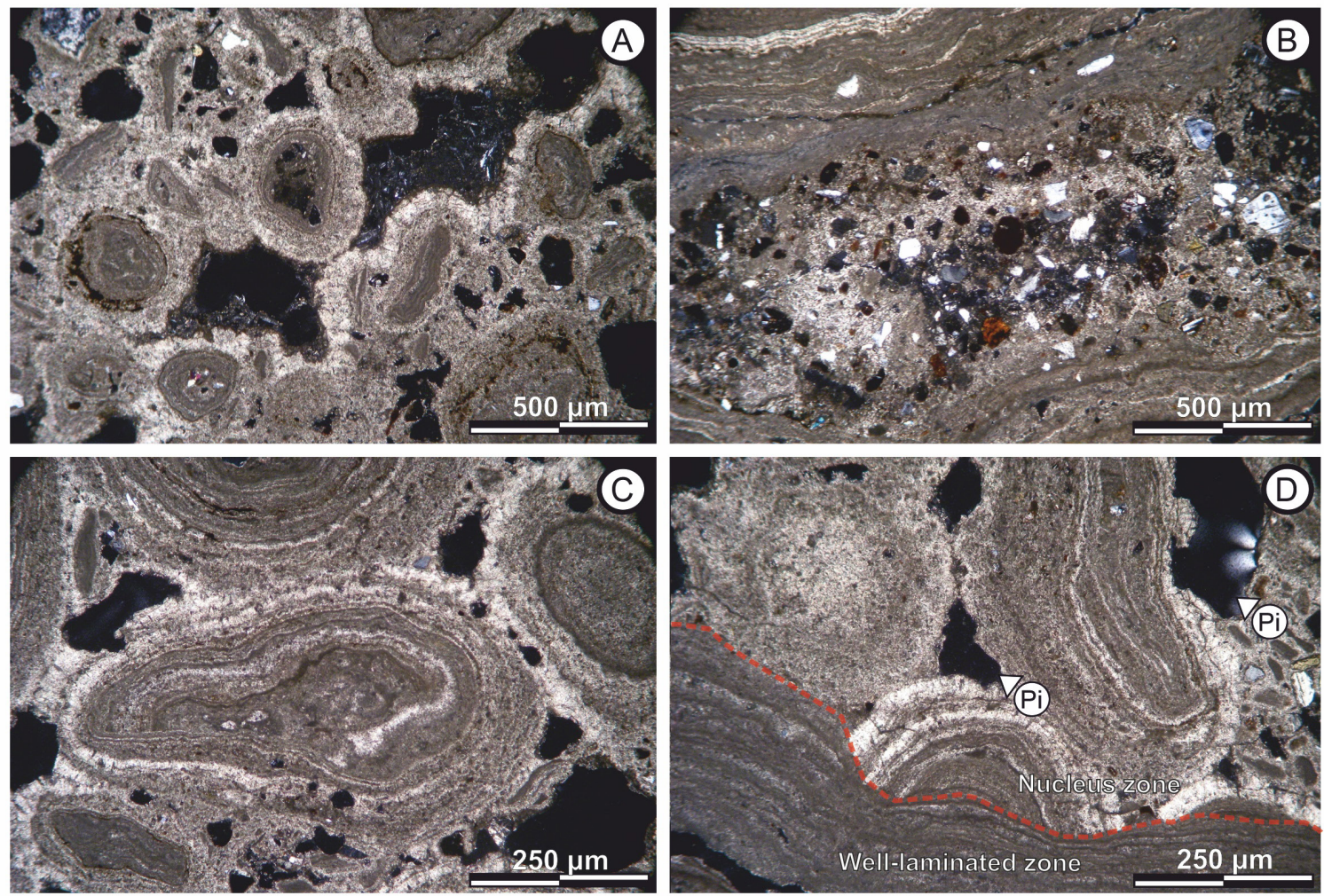

FIG. 8. Microphotograph (polarized light) of the nucleus zone. A. Type 2 nuclei composed of clastic material (with a poor degree of selection) and mini-oncoids. All immersed in a micritic matrix. B. Type 1 nuclei composed of clastic material (less than $0.25 \mathrm{~mm}$ ) like minerals, rock fragments, or even reworked micritic intraclasts. All immersed in a micritic matrix. C. Mini-oncoids presents in type 2 nuclei. D. Non-selective factory porosity, of intraclasts and intragranular type (Pi). Well-laminated zone is observed cutting the nuclei structures (red dotted line).

poorly-laminated zone. However, there are not differences in the DNA composition of these two zones. In the nucleus zone no organic useful remains for biodiversity studies were found.

Studies show a high microbiological diversity in Las Quínoas oncoids. The taxonomic classification reveals that they are mainly inhabited by Proteobacteria (ca. 37.5\%), Bacteroidetes (ca. 25.0\%) and in less proportion Planctomycetes, Actinobacteria and Cyanobacteria (Fig. 11). In regard of majority Class the most abundant corresponds to Alphaprotebacteria (ca. 25.0\%), Bacteroidia (ca. 18.0\%) and Gammaproteobacteria (ca. 13.0\%). Despite using primers that amplify sequences of both bacteria and archaea (Klindworth et al., 2013), the sequences obtained belonging to archaea are less than $1 \%$ abundance.

\section{Discussion}

\subsection{Distribution of oncoids and external morphology}

In general, oncoids usually limit their spatial distributions to restricted local areas, within a sedimentary environment (Dahanayake et al., 1985; Jones and Goodbody, 1985; Gómez et al., 2014). These spatial limitations are conditioned in most cases by extrinsic parameters such as the energy of the environment, water chemistry and influx of sediments, among other (Grotzinger and Knoll, 1999). The case of Las Quínoas is not an exception, since its oncoids are formed along channels and small fans, product of the hydrochemistry, sediment input and the microbial activity. The location of groundwater springs, the climatic influence (wide daily thermic 

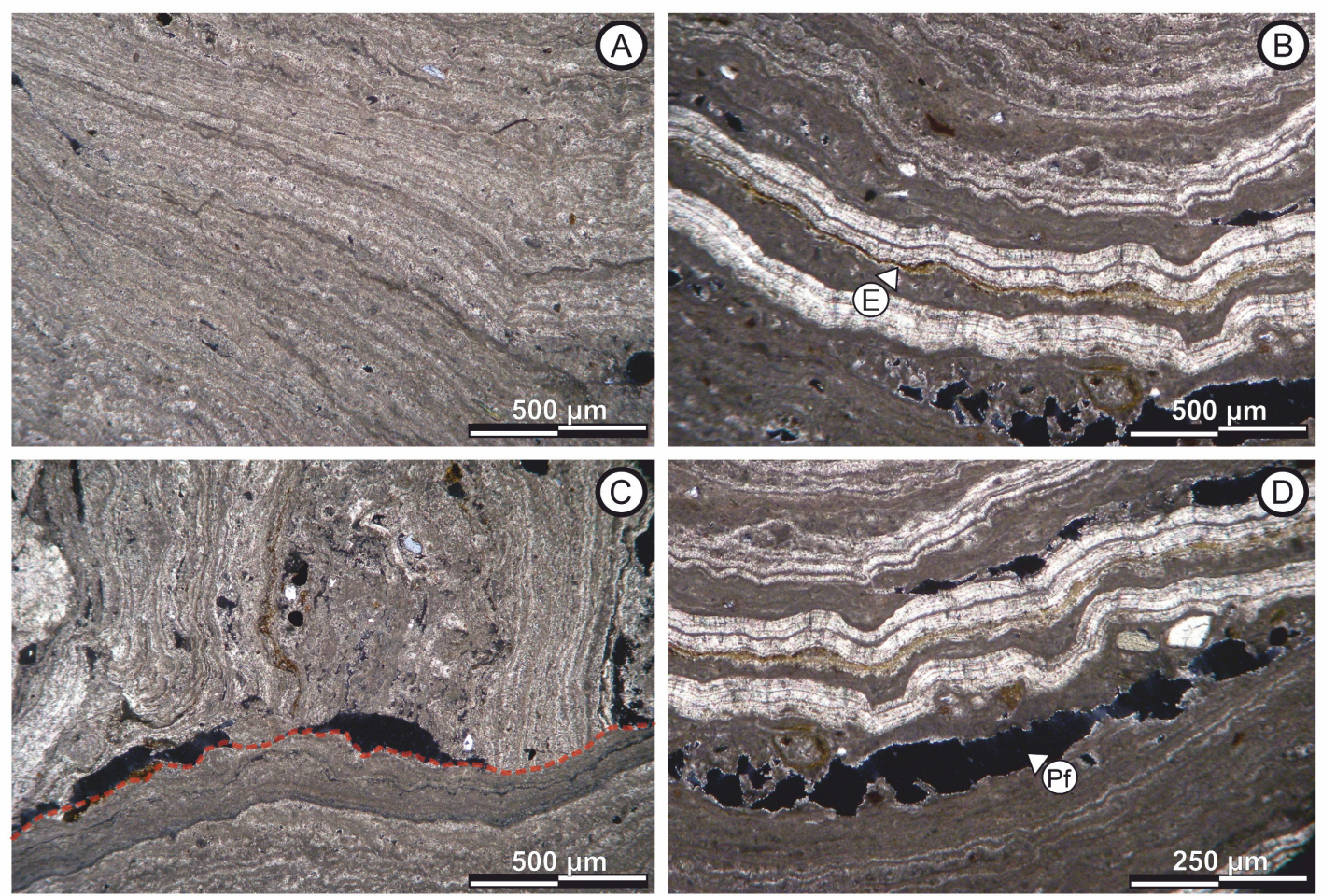

FIG. 9. Microphotograph (polarized light) of the well-laminated zone. A. Alternation of dense and dark micritic laminae with light micritic to microsparitic laminae. B. The presence of sparite laminae $(\mathbf{E})$, interspersed with micritic lamination, is sporadically differentiated. C. Two lamination packages with different orientation separated by discontinuities (red dotted line). One package is interrupted and new lamination packages grow overlapping with a new direction. D. Selective factory porosity of the fenestral type (Pf).

amplitudes and summer rainfall, hail and snow from December to April) in the local hydrology and sedimentology, and the salt flat position, along with the location of water mixing areas, control the mineral saturation for the development of oncoids. This suggests a clear association between these microbialites and the groundwater supply areas, as indicated for analogous deposits (Risacher and Eugster, 1979; Jones and Renault, 1994; Gómez et al., 2014).

The channels exert control over the growth of oncoids. First, the chemical conditions of the water in the channels, with a progressive enrichment in $\mathrm{Ca}$ and $\mathrm{Mg}$ towards the salt flat (Table 1), together with relatively neutral $\mathrm{pH}$, generate an optimal system for carbonate precipitation and the growth of oncoids (Gómez et al., 2014). On the other hand, the water level in the channels will also play an important role in controlling the growth of oncoids, since the air/ water interface will limit their growth space.
Based on this, we can suggest that oncoids with sub-rounded morphologies have formed in the distal and central part of the channels, below the water/air interface, favored by their chemical conditions (Fig. 6). As the oncoids are transported along the channels in the direction of the salt flat, and remain below the water/air interface, their size increases as a result of the mineral precipitation and/or trapping and binding of clastic material. This transport is episodic due to seasonal changes in water streams and processes like daily water freezing and thawing (Fig. 6).

When the size of the oncoids reaches the point where the hydrodynamic energy of the system is insufficient to continue with its transport, and the water level (depth) limits the vertical growth, the oncoids grow laterally and suffer asymmetric thickening (Shi and Chen, 2006) product of contributions and/ or preferential precipitation below the air-water interface (Gómez et al., 2014). This gives rise to overgrowth and development of discoidal shapes 

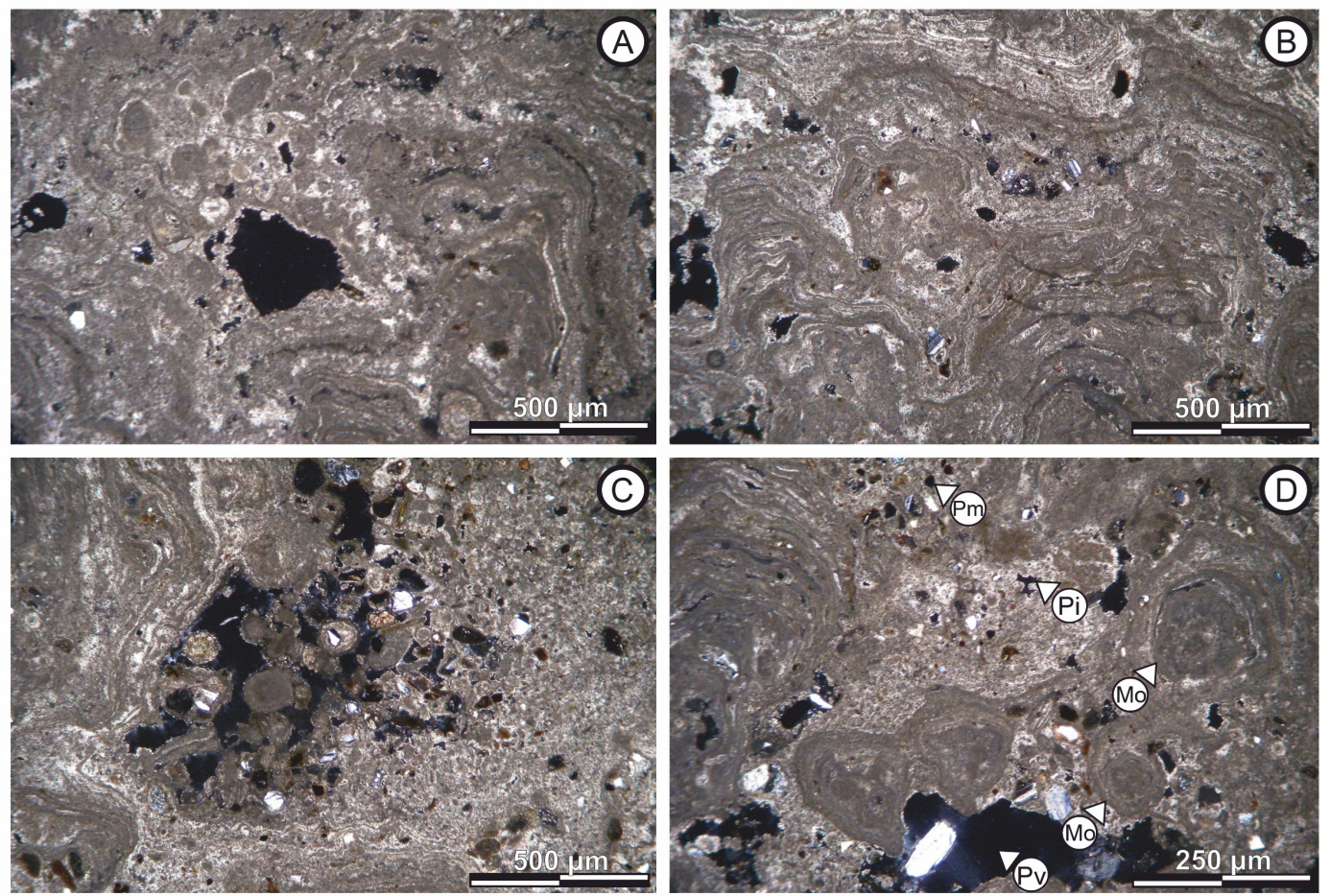

FIG. 10. Microphotograph (polarized light) of the poorly-laminated zone. A-B. The microstructure of the poorly-laminated zone composed by the alternation of dense and dark micritic laminae, with lighter micritic to microsparitic laminae. The laminae have high sinuosity and are interrupted laterally. C. The non-laminated sectors are composed of clastic material with a poor degree of selection, immersed in a matrix of micritic composition. The clasts are less than $0.1 \mathrm{~mm}$ and may be composed of minerals, rock fragments and reworked micritic intraclasts. D. Presence of mini-oncoids (Mo), vug porosity (Pv), intragranular porosity (Pi) and moldic porosity (Pm).

and larger sizes, mainly in the discharge area of the channels in the salt flat (channels proximal area) where the availability of $\mathrm{Ca}$ in the water is also higher that in the central a distal areas (Fig. 6 and Table 1).

\subsection{Internal morphology}

The internal structure of Las Quínoas oncoids is variable, and it is the product of a combination of environmental (physical-chemical) and biological agents during their growth as it has been interpreted by Gómez et al. (2014) in other present-day oncoids from Laguna Negra. Because of its internal macrostructure we can classify these oncoids as simple C-type (concentric), or simply referred to as concentric, according to the works of Aitken (1967) and Mingxiang (2007).

Concentric morphology could be favored by episodic rotations or suspensions by water freezing- thawing. However, Jones and Renault (1994) suggest that none of these factors is necessary for concentric growth. The accumulation in the lower parts can occur through a porous substrate, literally raising the oncoids on the substrate (Jones and Renault, 1994). This is a possible mechanism for Las Quínoas oncoids due to the low-energy hydrodynamic conditions in the channels.

In the growth of this oncoids, different stages can be recognized. These start with a nucleus (described as nucleus zone), with later growth characterized by the development of well-and poorly-laminated zones. Initially, the nucleus is formed by rock fragments, carbonate crusts and micritic intraclasts, together with mini-oncoids (for example in the nuclei type 2 ). These elements were previously reworked and then cemented into a carbonate matrix, forming the aggregates that characterize the nucleus of most oncoids. On the other hand, the edges of the 

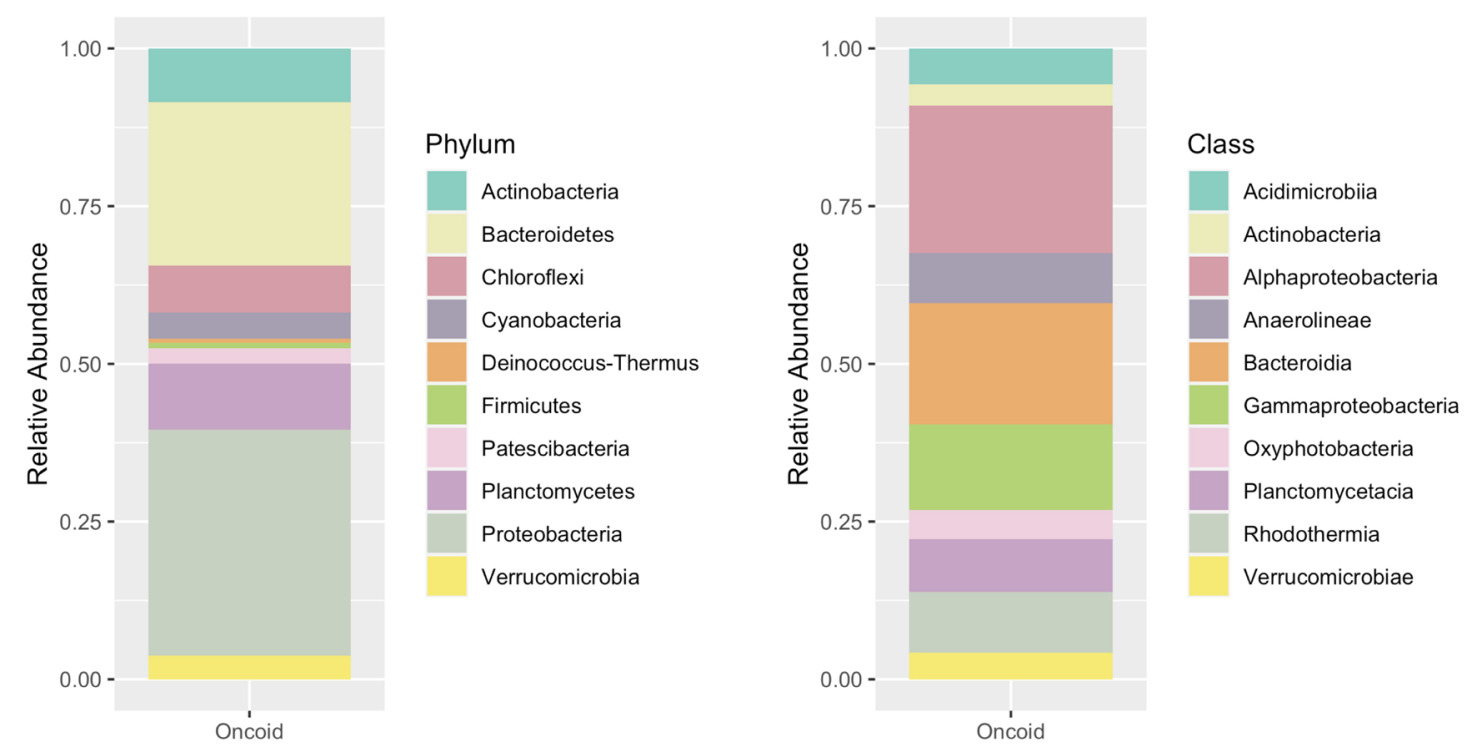

FIG. 11. Ten more representative Phylum-level and Class-level abundance based on 16S rRNA sequence classification. Vertical bars reflect the relative abundance of $16 \mathrm{~S}$ rRNA sequences assigned to each category using QIIME 2 and results were analyzed in phyloseq package in R. Proteobacteria and Bacteroidetes represent the major groups present in Las Quínoas oncoids. In regard to Class-level, the most abundant sequences belong to Alphaproteobacteria.

nucleus zone suggest that the nuclei could have been occasionally transported prior to the development of the well-laminated zone. These can be show at its edges, where the structures that make up the nucleus (e.g., mini-oncoids) are cut and the lamination of the well-laminated zone grows over a previously eroded and transported surface (Fig. 8D).

Around the nucleus a well-laminated zone is generated. Its growth begins in the most distal part of the channels and continue inside, due to the progressive increasing in $\mathrm{Ca}$ and $\mathrm{Mg}$ as well as carbonate saturation in the water of the channels, product of the mixing with the brine of the salt flat and/or the dissolution of carbonates and sulfates as the water course advances into de the salt flat (Fig. 6 and Table 1). As the oncoids grows, the well laminated zone is developed, where carbonate precipitation is triggered due to progressive evaporation and $\mathrm{CO}_{2}$ degassing along the flow path, as commonly observed in similar systems (Gómez et al., 2014, Beeler et al., 2020).

The mesostructure in the well-laminated zone varies from concentrically stacked spheroids (SS-C) (closer to the nucleus) to randomly stacked hemispheroids (SS-R) (further from the nucleus).
As has been interpreted by Boidi et al. (2020) in other present-day oncoids from Laguna Negra, the internal laminae microstructure and textural variations are probably triggered by local environmental changes (e.g., summer rainfall) as well as changes in microbial influence during lamina precipitation and accretion. The SS-C and the SS-R have the same microstructure (alternation of dark micritic and light micritic to microsparitic laminae), so a possible explanation for the overlapping overgrowths that generate the SS-R mesostructure is lamina accretion during episodic in situ oncoid rotation by cryoturbation-related processes (Gómez et al., 2014; Boidi et al., 2020). However, other environmental factors originated by seasonal and daily variations, such as episodic changes in the water energy producing rotation together with variations in the local hydrochemical conditions (fluctuating carbonate saturation levels), cannot be ruled out.

The microtexture of the laminae (dark micritic and light micritic to microsparitic) suggests that the growth of the oncoids is controlled by the insitu precipitation of carbonate (Reid et al., 2000), influenced by the microbial activity (well-developed biofilms) as has been interpreted by Gómez et al. (2014) in other 
present-day oncoids from Laguna Negra. Nevertheless, episodic changes in the nucleation and crystal growth stages during carbonate crystallization processes may generate the alternation between micritic and microsparitic laminae (Riding, 2000; Dupraz et al., 2009). This may occur due to different processes that can influence crystal nucleation and growth, such as changes in the precipitation rate, changes in oversaturation, fluctuation of carbonate and calcium concentration and level of organic activity (Hu et al., 2012; Giuffre et al., 2013; Dobberschütz et al., 2018; Li and Jun, 2019). On the other hand, isolated clotted-micritic laminae may be due localized microcrystalline carbonate nucleation associated to organic matrix (within biofilms) as well as related with the clastic contribution of sporadic events like winds or storms, while sparite-associated laminae may be due to desiccation episodes triggering oversaturation and higher precipitation rates.

Occasionally were the oncoids are partially subaerially exposed, preferential growth below the air-water or at sediment-water interface produce lateral protrusions developing discoidal morphologies. This preferential lateral growth is represented by a poorly-laminated zone, which cover the well-laminated zone (Fig. 6). The poorly-laminated zone developed under a greater detrital sediments contribution when compared with the well-laminated zone. Locally, its mesostructure shows the growth of sinuous, irregular and laterally discontinuous laminae (with the same microtexture as in well-laminated zone), developed over preexisting irregularities, product of the incorporation of clastic material during laminae accretion. Elsewhere, the content of clastic material increases and prevents the formation of well-developed or continuous laminae, giving rise to a wackestones-packstones microstructure. The sedimentary contribution is regulated mainly by two factors: i) the carbonate supersaturation in the water, which influences the precipitation of micrite and controls the generation of calcareous particles (mini-oncoids, carbonate scabs, etc.), and ii) the contribution of clastic material, possibly regulated by external climatic agents, such as increases in the hydrodynamic energy, sporadic storms or wind.

The types of pores present in the oncoids are diverse. However, applying the genetic classification proposed by Ahr et al. $(2005,2011)$, a depositional origin is suggested, possibly favored by the circulation of fluids. The exception to this would be fenestral porosity, that may be due by two processes acting individually or together: i) a parallel shrinkage to the lamination product of the desiccation thereof (Alonso et al., 1987), or ii) the release and calcification of gas bubbles (due to the putrefaction of the organic matter that composes the oncoids) as well as the voids left after organic matter degradation (SanzMontero et al., 2005).

\subsection{Biodiversity studies}

The growth and development of microbialites is controlled in part by intrinsic factors (microbial mat), which may be represented by a wide variety of microbial organisms such as bacteria, archaea, cyanobacteria and algae among others (Dupraz et al., 2006; Riding, 2008). These kinds of ecosystems constitute a natural laboratory for exploring and monitoring in situ interactions between the physical background and the dynamics of biodiversity; knowing the microbial biodiversity and its possible metabolic pathways, better interpretations about global morphogenesis of the microbialites and the lithification process can be done (Dupraz et al., 2006; Suosaari et al., 2016).

In terms of bacterial composition, the oncoids of Las Quínoas have a greater abundance of Bacteroidetes, and Proteobacteria (Fig. 11), these results agree with our previous studies where these bacterial phyla appear to be dominant in ecosystems such as: microbialites, microbial mats and sediments from high-altitude Andean lakes (Albarracín et al., 2015; Farías et al., 2014, 2017; Solon et al., 2018; Toneatti et al., 2017; Rasuk et al., 2016).

Bacteroidetes could have a key role in macromolecules degradation (particularly extracellular polymeric subtances or EPS) (Rudivindy et al., 2016; Marvasi et al., 2012). The EPS degradation is assumed to be a critical step in carbonate precipitation. On the other hand, Anoxygenic phototrophs like Alphaproteobacteria, Gammaproteobacteria, and Chloroflexi are widely abundant in the surface of oncoids (Fig. 11). This anoxygenic phototrophic metabolism could favor precipitating carbonate minerals (Vissher and Stolz, 2005). Sulfur oxidizers like Gammaproteobacteria were well represented, with close to $12 \%$ relative abundance (Fig. 11). Their role in carbonate dissolution has been studied in this kind of system where its metabolism could help in the balance of mineral precipitating and 
mineral dissolution processes, potentially resulting in lithification (Vissher and Stolz, 2005; Vissher et al., 1998; Farías et al., 2017). Others phylum present are Planctomycetes, little known and relatively uncharacterized phylogenetic group, are able to perform anaerobic ammonium oxidation, perhaps is fulfilling a significant role that might have implications in the sediment and atmosphere nitrogen cycle (van Niftrik and Jetten, 2012).

On the other hand, there was low abundance of Cyanobacteria ( $c a .4 \%$ ) habiting oncoids of Las Quínoas, while the oncoids of Rio Mesquites in Mexico have $76 \%$ of Cyanobacteria, being the oncoids with greater presence of Cyanobacteria (44\% of them belonging to order Nostocales) (Garcia-Pichel et al., 2004). The low abundance of Cyanobacteria can be understood due to their high sensitivity to environmental stresses such as UV radiation and high salt concentration (Cabrol et al., 2009; Albarracín et al., 2015), suggesting that they might not be playing an essential role related to carbon fixation and as producers of extracellular polymeric subtances (EPS).

\section{Conclusions}

Las Quínoas is characterized by rounded to sub-rounded and discoidal oncoids, distributed along channels and small fans, in a transition area between Las Quínoas wetland and the salt flat (Salar de Antofalla). The development of the oncoids is controlled mainly by the degree of carbonate supersaturation in the water and if this supersaturation is sustained over time. However, the water depth and flow energy along the channels play an important role limiting oncoids growth, together with an episodic transport.

The internal mesostructure of Las Quínoas oncoids it's concentric and three zones can be defined: nucleus zone, well-laminated zone and a poorly-laminated zone.

The growth begins from a nucleus zone, formed by lithic fragments, carbonate crusts and micritic intraclasts, sometimes together with mini-oncoids. These elements were reworked and cemented into a carbonate matrix, forming aggregates to give origin to the nucleus, that later can be transported.

Around the nuclei, the well-laminated zone is develops composed by an alternation of dense and dark micritic laminae with light micritic to microsparitic laminae. As the oncoids are transported along the channels, well-laminated zone increases as a result of the mineral precipitation and/or trapping and binding. This transport is episode due to seasonal changes in water streams and processes like daily water freezing and thawing and throughout this the mesostructure of this well-laminated zone varies from concentrically stacked spheroids (SS-C) to randomly stacked semispheroids (SS-R).

In channels proximal area (fan/discharge), the hydrodynamic energy is insufficient to continue with the oncoids transport, and the water level limits the vertical growth. In this area, favored by the sedimentary contribution, the poorly-laminated zone of the oncoids grows laterally suffering asymmetric thickening. Locally, the mesostructure of the poorly-laminated zone shows sinuous, irregular and discontinuous laminae (with a comparable microtexture as in welllaminated zone). Occasionally, the content of clastic material episodically increases and prevents the formation of continuous or regular laminae as shown by zones with abundant trapped detrital material.

Biodiversity analysis reveals that the oncoids are inhabited mostly by Proteobacteria ( $c a .37 .5 \%$ ), Bacteroidetes ( $c a$. 25.0\%), and in less proportion Planctomycetes, Actinobacteria and Cyanobacteria. The microbial taxonomy of the oncoids present in Las Quínoas is dominated almost entirely by bacteria. The abundance of some microorganism not easily assigned to known groups highlights the potential of these systems regarding the presence of the poly-extremophiles organisms in terms of new metabolisms controlling mineralization processes and their biotechnological applications.

\section{Acknowledgment}

This work was carried out in the framework of the project PICT 2015 No 3825. Préstamo BID. “Obtención de energía a partir del arsénico en microbialitos de la Puna: Una conexión con la vida en el planeta primitivo".

The tour guide and photographer L. Ahumada is thanked for providing the photographs of the work area, used for the realization of figure 2. Upon the advice of Ph.D. D. Poiré (Centro de Investigaciones Geológicas de la Universidad de La Plata, UNLP-CONICET) for the preparation of the polished samples and thin cuts. We also thank Ph.D. C. Cónsole Gonella (Instituto Superior de Correlación Geológica, UNT-CONICET) for collaborating in the capture of images with the petrographic microscope. 
Thanks are given to Ph.D. W. Vivallo, Ph.D. A. Sáez and to an anonymous reviewer for their valuable comments and suggestions on the manuscript.

\section{References}

Ahr, W.M.; Allen, D.; Boyd, A.; Bachman H.M.; Smithson T. 2005. Confronting the carbonate conundrum. Oilfield Review: 18-29.

Ahr, W.M.; Mancini, E.A.; Parcell, W.C. 2011. Pore characteristics in microbial carbonate reservoirs. AAPG Search \& Discovery Article 30167: 10-13.

Aitken, J.D. 1967. Classification and environmental significance of cryptalgal limestones and dolomites. Journaly of Sedimentology and Petrology 37: 1163-1178.

Albarracín, V.H.; Kurth, D.; Ordoñez, O.F.; Belfiore, C.; Luccini, E.; Salum, G.M.; Farías, M.E. 2015. High-Up: a remote reservoir of microbial extremophiles in Central Andean wetlands. Frontiers in Microbiology 6: 1404.

Albarracín, V.H.; Gärtner, W.; Farías, M.E. 2016. Forged Under the Sun: Life and Art of Extremophiles from Andean Lakes. Photochemistry and Photobiology 92 (1): 14-28.

Alonso, R.N.; Viramonte, J.; Gutiérrez, R. 1984. Puna Austral. Bases para el subprovincialismo geológico de la Puna argentina. In Congreso Geológico Argentino, No. 9, Actas 1: 43-63. San Carlos de Bariloche.

Alonso, F.J.; Esbert, R.M.; Ordaz, J. 1987. Caracterización del sistema poroso de calizas y dolomías. Boletín Geológico y Minero 98: 226-237.

Alonso, R.N.; Bookhagen, B.; Carrapa, B.; Coutand, I.; Haschke, M.; Hilley, G.E.; Schoenbohm, L.; Sobel, E.R.; Strecker, M.R.; Trauth, M.H.; Villanueva, A. 2006. Tectonics, Climate, and Landscape Evolution of the Southern Central Andes: the Argentine Puna Plateau and Adjacent Regions between 22 and $30^{\circ} \mathrm{S}$. In The Andes: Active Subduction Orogeny (Oncken, O.; Chong, G.; Franz, G.; Giese, P.; Götze, H.J.; Ramos, V.A.; Strecker, M.R.; Wigger, P.; editors). Springer: 265-283. Heidelberg.

Beeler, S.R.; Gómez, F.J.; Bradley, A.S. 2020. Controls of extreme isotopic enrichment in modern microbialites and associated abiogenic carbonates. Geochimica et Cosmochimica Acta 269: 136-149.

Boidi, F.J.; Mlewski, C.; Gómez, F.J.; Gerard, E. 2020. Characterization of microbialites and microbial mats of the Laguna Negra hypersaline lake (Puna of Catamarca, Argentina). In Microbial Ecosystems in Central Andes Extreme Environments (Farías, M.E.; editor). Springer: 183-204. Switzerland.
Burne, R.V.; Moore, L.S. 1987. Microbialites: organosedimentary deposits of benthic microbial communities. Palaios 2: 241-254.

Cabrol, C.; Huzarska, M.A.; Dinolfo, C.; Rodríguez, M.C.; Reinstatler, L.; Ni, J.; Leissring, M.A. 2009. Small-molecule activators of insulin-degrading enzyme discovered through high-throughput compound screening. PLoS ONE 4 (4): e5274.

Cajal, J.L. 1998. Las unidades morfoestructurales, el clima, la vegetación y las poblaciones humanas en la Puna y cordillera frontal. In Bases para la conservación y manejo de la Puna y Cordillera Frontal de Argentina. El rol de las reservas de biosfera (Cajal, J.L.; García Fernández, J.J.; Tecchi, R.; editors). FUCEMAUNESCO: 9-24. Buenos Aires.

Caporaso, J.G.; Kuczynski, J.; Stombaugh, J.; Bittinger, K.; Bushman, F.D.; Costello, E.K. 2010. QIIME allows analysis of high-throughput community sequencing data. Nature Methods 7 (5): 335-336.

Choquette, P.W.; Pray, L.C. 1970. Geologic nomenclature and classification of porosity in sedimentary carbonates. The American Association of Petroleum Geologists, Bulletin 54 (2): 207-250.

Cohen, A.S.; Talbot, M.R.; Awramik, S.M.; Dettman, D.L.; Abell, P. 1997. Lake level and paleoenvironmental history of Lake Tanganyika, Africa, as inferred from late Holocene and modern stromatolites. Geological Society of American, Bulletin 109 (4): 444-460.

Conhidro, S.R.L. 2016. Estudio Hidrogeológico Río Los Patos. Salar del Hombre Muerto, Provincia de Catamarca. Technical report. Minera del AltiplanoFMC Lithium: $81 \mathrm{p}$.

Dahanayake, K.; Gerdes, G.; Krumbein, W.E. 1985. Stromatolites, oncolites and oolites biogenically formed in situ. Naturwissenschaften 72 (10): 513-518.

Dexit, P.C. 1984. Pleistocene lacustrine ridged oncolites from the Lake Manyara area, Tanzania, East Africa. Sedimentary Geology 39 (1-2): 53-62.

Dobberschütz, S.; Nielsen, M.R.; Sand, K.K.; Civioc, R.; Bovet, N.; Stipp, S.L.S.; Andersson, M.P. 2018. The mechanisms of crystal growth inhibition by organic and inorganic inhibitors. Nature Communications 9 (1): 1-6.

Dunham, R.J. 1962. Classification of carbonate rocks according to depositional texture. In Classification of Carbonate Rocks (Ham, W.E.; editor). American Association of Petroleum Geologists Memoir: 108-121. Arizona.

Dupraz, C.; Pattisina, R.; Verrecchia, E.P. 2006. Translation of energy into morphology: simulation of stromatolite morphospace using a stochastic model. Sedimentary Geology 185 (3-4): 185-203. 
Dupraz, C.; Reid, R.P.; Braissant, O.; Decho, A.W.; Norman, R.S.; Visscher, P.T. 2009. Processes of carbonate precipitation in modern microbial mats. Earth-Science Reviews 96 (3): 141-162.

Dupraz, C.; Reid, R.P.; Visscher, P.T. 2011. Microbialites, Modern. In Encyclopedia of Geobiology (Reitner, J.; Thiel, V.; editors), Enciclopedia of Earth Sciences Series. Springer: 6517-635. Heidelberg.

Farías, M.E. 2017a. Relevamiento y caracterización preliminar de microbialitos modernos en el salar de Antofalla. Informes para la Secretaria de Minería de Catamarca (Inédito), Proyecto PIO UNCA: 18 p.

Farías, M.E. 2017b. Informe otoño Línea de Base Antofalla (8-26 Mayo 2017). Línea de Base proyecto Salar de Antofalla, CONICET- Albemarle: 175 p.

Farías, M.E.; Poiré, D.G.; Arrouy, M.J.; Albarracín, V.E. 2011. Modern stromatolite ecosystems at alkaline and hypersaline high-altitude lakes in the Argentinean Puna. In Stromatolites: interaction of microbes with sediments (Tewari, V.; Seckbach, J.; editors). Springer Science \& Business Media: 431-441. Dordrecht.

Farías, M.E.; Contreras, M.; Rasuk, M.C.; Kurth, D.; Flores, M.R.; Poire, D.G; Visscher, P.T. 2014. Characterization of bacterial diversity associated with microbial mats, gypsum evaporites and carbonate microbialites in thalassic wetlands: Tebenquiche and La Brava, Salar de Atacama, Chile. Extremophiles 18 (2): 311-329.

Farías, M.E.; Rasuk, M.C.; Gallagher, K.L.; Contreras, M.; Kurth, D.; Fernández, A.B.; Poiré, D.; Novoa, F.; Visscher, P.T. 2017. Prokaryotic diversity and biogeochemical characteristics of benthic microbial ecosystems at La Brava, a hypersaline lake at Salar de Atacama, Chile. PLoS ONE 12 (11): e0186867. doi: 10.1371/journal.pone.0186867.

Garcia-Pichel, F.; Al-Horani, F.A.; Farmer, J.D.; Ludwig, R.; Wade, B.D. 2004. Balance between microbial calcification and metazoan bioerosion in modern stromatolitic oncolites. Geobiology 2 (1): 49-57.

Gebelein, C.D. 1976. Open marine subtidal and intertidal stromatolites (Florida, the Bahamas and Bermuda). In Stromatolites (Walter, M.R.; editor). Elsevier: 381-388. Amsterdam.

Giuffre, A.J.; Hamm, L.M.; Han, N.; De Yoreo, J.J.; Dove, P.M. 2013. Polysaccharide chemistry regulates kinetics of calcite nucleation through competition of interfacial energies. Proceedings of the National Academy of Sciences 110 (23): 9261-9266.

Gómez, F.J.; Kah, L.C.; Bartley, J.K.; Astini, R.A. 2014. Microbialites in a high-altitude Andean lake: Multiple controls on carbonate precipitation and lamina accretion. Palaios 29 (6): 233-249.

Grotzinger, J.P.; Knoll, A.H. 1999. Stromatolites in Precambrian carbonates: Evolutionary mileposts or environmental dipsticks? Annual Reviews of Earth and Planetary Sciences 27: 313-358.

Hongn, F.D.; Seggiaro, R.E. 2001. Hoja Geológica 2566-III, Cachi. Provincias de Salta y Catamarca. Instituto de Geología y Recursos Minerales, Servicio Geológico Minero Argentino. Boletín 248: 94 p. Buenos Aires.

Houston, J.; Butcher, A.; Ehren, P.; Evans, K.; Godfrey, L. 2011. The Evaluation of Brine Prospects and the Requirement for Modifications to Filing Standards. Economic Geology 106 (7): 1225-1239.

Hu, Q.; Nielsen, M.H.; Freeman, C.L.; Hamm, L.M.; Tao, J.; Lee, J.R.I.; De Yoreo, J.J. 2012. The thermodynamics of calcite nucleation at organic interfaces: Classical vs. non-classical pathways. Faraday Discussions 159 (1): 509-523.

Jones, B.; Goodbody, Q.H. 1985. Oncolites from a shallow lagoon, Grand Cayman Island. Bulletin of Canadian Petroleum Geology 33 (2): 254-260.

Jones, B.; Renault, R.W. 1994. Crystal fabrics and microbiota in large pisoliths from Laguna Pastos Grandes, Bolivia. Sedimentology 41: 1171-1202.

Jordan, T.E.; Mpodozis, C. 2006. Estratigrafía y evolución tectónica de la cuenca Paleógena Arizaro-Pocitos, Puna Occidental. In Congreso Geologico Chileno, No 11, Actas 2: 24-25. Antofagasta.

Klindworth, A.; Pruesse, E.; Schweer, T.; Peplies, J.; Quast, C.; Horn, M.; Glöckner, F.O. 2013. Evaluation of general 16S ribosomal RNA gene PCR primers for classical and next-generation sequencing-based diversity studies. Nucleic acids research 41 (1): e1. doi: 10.1093/nar/gks808.

Kraemer, B.; Adelmann, D.; Alten, M.; Schnurr, W.; Erpenstein, K.; Kiefer, E.; Gorler, K. 1999. Incorporation of the Paleogene foreland into the Neogene Puna plateau: the Salar de Antofalla area, NW Argentina. Journal of South American Earth Sciences 12 (2): 157-182.

Lanes, S.; Palma, R.M. 1998. Environmental implications of oncoids and associated sediments from the Remoredo Formation (Lower Jurassic) Mendoza, Argentina. Palaeogeography, Palaeoclimatology, Palaeoecology 140 (1-4): 357-366.

Li, Q.; Jun, Y.S. 2019. Salinity-Induced Reduction of Interfacial Energies and Kinetic Factors during Calcium Carbonate Nucleation on Quartz. The Journal of Physical Chemistry 123 (23): 14319-14326. 
Logan, B.W.; Rezak, R.; Ginsburg, R.N. 1964. Classification and environmental significance of algal stromatolites. The Journal of Geology 72: 68-83.

Marvasi, M.; Gallagher, K.L.; Martinez, L.C.; Molina Pagan, W.C.; Rodríguez Santiago, R.E.; Castilloveitía Vega, G.; Visscher, P.T. 2012. Importance of B4 Medium in Determining Organomineralization Potential of Bacterial Environmental Isolates. Geomicrobiology Journal 29 (10): 916-924.

McMaster, R.L.; Conover, J.T. 1966. Recent algal stromatolites from the Canary Islands. The Journal of Geology 74 (5): 647-652.

Mercedes Martín, R.; Salas, R.; Arenas, C. 2014. Microbial-dominated carbonate platforms during the Ladinian rifting: sequence stratigraphy and evolution of accommodation in a fault-controlled setting (Catalan Coastal Ranges, NE Spain). Basin Research 26 (2): 269-296.

Mingxiang, M.E.I. 2007. Revised classification of microbial carbonates: complementing the classification of limestones. Earth Science Frontiers 14 (5): 222-232.

Monty, C.L. 1976. The Origin and Development of Cryptalgal Fabrics. In Developments in sedimentology (Walter, M.R.; editor). Elsevier: 193-249. Amsterdam.

Moore, L.S. 1993. The modern microbialites of Lake Clifton, south-western Australia. Ph.D. Thesis (Unpublished), University of Western Australia: 1-178.

Pettijohn, F.J.; Potter, P.E.; Siever, R. 1973. Sand and sandstone. Heidelberg: 618 p. Berlin.

Rasuk, M.C.; Fernández, A.B.; Kurth, D.; Contreras, M.; Novoa, F.; Poiré, D.; Farías, M.E. 2016. Bacterial diversity in microbial mats and sediments from the Atacama Desert. Microbial Ecology 71 (1): 44-56.

Reid, R.P.; Visscher, P.T.; Decho, A.W.; Stolz, J.F.; Bebout, B.M.; Dupraz, C.; Macintyre, I.G.; Paerl, H.W.; Pinckney, J.L.; Prufert Beboult, L.; Steepe, T.F.; Des Marais, D.J. 2000. The role of microbes in accretion, lamination and early lithification of modern marine stromatolites. Nature 406: 989-992.

Reid, R.P.; James, N.P.; Macintyre, I.G.; Dupraz, C.P.; Burne, R.V. 2003. Shark Bay stromatolites: microfabrics and reinterpretation of origins. Facies 49: 299-324.

Riding, R.E. 1977. Skeletal stromatolites. In Fossil Algae (Flügel, E.; editor). Springer-Verlag: 57-60. Berlin.

Riding, R.E. 2000. Microbial carbonates: the geological record of calcified bacterial-algal mats and biofilms. Sedimentology 47: 179-214.
Riding, R.E. 2008. Abiogenic, microbial and hybrid authigenic carbonate crusts: components of Precambrian stromatolites. Geologica Croatia 61: 73-103.

Risacher, F.; Eugster, H.P. 1979. Holocene pisoliths and encrustations associated with spring-fed surface pools, Pastos Grandes, Bolivia. Sedimentology 26 (2): 253-270.

Rouchy, J.M.; Servant, M.; Fournier, M.; Causse, C. 1996. Extensive carbonate algal bioherms in upper Pleistocene saline lakes of the central Altiplano of Bolivia. Sedimentology 43: 973-993.

Ruvindy, R.; White III, R.A.; Neilan, B.A.; Burns, B.P. 2016. Unravelling core microbial metabolisms in the hypersaline microbial mats of Shark Bay using high-throughput metagenomics. The ISME Journal 10 (1): 183-196.

Sanz-Montero, M.E.; Rodríguez-Aranda, J.P.; Calvo, J.P. 2005. Biomineralization in relation with endoevaporitic microbial communities. Miocene lake deposits of the Madrid Basin, Central Spain. Geophysical Research Abstract 7: 68-74.

Sarjeant, W.A.S. 1975. Plant trace fossils. In The study of trace fossils (Frey, R.W.; editor). Springer- Verlag: 163-179. New York.

Scholle, P.A. 1978. A color illustrated guide to carbonate rock constituents, textures, cements, and porosities. The American association of Petroleum Geologists. Springer-Verlag: 241 p. Berlin.

Schopf, J.W. 1996. Cyanobacteria: pioneers of the early Earth. Nova Hedwigia Beiheft 112: 13-32.

Shapiro, R.S.; Awramik, S.M. 2000. Microbialite morphostratigraphy as a tool for correlating Late Cambrian-Early Ordovician sequences. The Journal of Geology 108 (2): 171-180.

Shi, G.R.; Chen, Z.Q. 2006. Lower Permian oncolites from South China: Implications for equatorial sealevel responses to Late Palaeozoic Gondwanan glaciation. Journal of Asian Earth Sciences 26 (3-4): 424-436.

Solon, A.J.; Vimercati, L.; Darcy, J.L.; Arán, P.; Porazinska, D.; Dorador, C.; Schmidt, S.K. 2018. Microbial communities of high-elevation fumaroles, penitentes, and dry tephra "soils" of the Puna de Atacama volcanic zone. Microbial Ecology 76 (2): 340-351.

Suárez-González, P.; Quijada, I.E.; Benito, M.I.; Mas, R.; Merinero, R.; Riding, R. 2014. Origin and significance of lamination in Lower Cretaceous stromatolites and proposal for a quantitative approach. Sedimentary Geology 300: 11-27. 
Suárez-González, P.; Benito, M.I.; Quijada, I.E.; Mas, R.; Campos-Soto, S. 2019. Trapping and binding: A review of the factors controlling the development of fossil agglutinated microbialites and their distribution in space and time. Earth-Science Reviews 194: 182-215.

Suosaari, E.P; Reid, R.P.; Araujo, T.A; Playford, P.E.; Holley, D.K.; Mcnamara, K.J.; Eberli, G.P. 2016. Environmental pressures influencing living stromatolites in Hamelin Pool, Shark Bay, Western Australia. Palaios 30 (10): 483-496.

Toneatti, D.M.; Albarracín, V.H.; Flores, M.R.; Polerecky, L.; Farías, M.E. 2017. Stratified bacterial diversity along physico-chemical gradients in high-altitude modern stromatolites. Frontiers in Microbiology 8: 646.

Tucker, M.E. 2009. Sedimentary petrology: an introduction to the origin of sedimentary rocks. Blackwell Science: 261 p. Oxford.

Valero-Garcés, B.L.; Arenas, C.; Delgado-Huertas, A. 2001. Depositional environments of Quaternary lacustrine travertines and stromatolites from high-altitude Andean lakes, northwestern Argentina. Canadian Journal of Earth Sciences 38 (8): 1263-1283.

Van Niftrik, L.; Jetten, M.S. 2012. Anaerobic ammoniumoxidizing bacteria: unique microorganisms with exceptional properties. Microbiology and Molecular. Biology Reviews 76 (3): 585-596.

Vennin, E.; Olivier, N.; Brayard, A.; Bour, I.; Thomazo, C.; Escarguel, G.; Fara, E.; Bylunds, K.G.; Jenks, J.F.;
Stephen, D.A.; Hofmann, R. 2015. Microbial deposits in the aftermath of the end-Permian mass extinction: A diverging case from the Mineral Mountains (Utah, USA). Sedimentology 62 (3): 753-792.

Verrecchia, E.P.; Freytet, P.; Julien, J.; Baltzer, F. 1997. The unusual hydrodynamical behaviour of freshwater oncolites. Sedimentary Geology 113 (3-4): 225-243.

Visscher, P.T.; Stolz, J.F. 2005. Microbial mats as bioreactors: populations, processes, and products. Palaeogeography, Palaeoclimatology, Palaeoecology 219: 87-100.

Visscher, P.T.; Reid R.P.; Bebout, B.M.; Hoeft, S.E.; Macintyre, I.G.; Thompson, J.A. 1998. Formation of lithified micritic laminae in modern marine stromatolites (Bahamas); the role of sulfur cycling. Mineralogical Society of America 83: 1482-1493.

Warden, J.G.; Coshell, L.; Rosen, M.R.; Breecker, D.O.; Ruthrof, K.X.; Omelon, C.R. 2019. The importance of groundwater flow to the formation of modern thrombolitic microbialites. Geobiology 17 (5): 536-550.

Zanin, Y.N.; Luchinina, V.A.; Levchuk, M.A.; Pisareva, G.M. 2001. Stromatolites and oncolites in Mesozoic deposits of the West Siberian Plate. Geologiya i Geofizika 42 (9): 1417-1420.

Ziai, H. 1982. Classification and origin of oncolite. Oil and Gas Geology 3 (1): 41-48.

Manuscript received: August 22, 2019; revised/accepted: June 30, 2020; available online: January 29, 2021. 